\title{
GCU
}

Glasgow Caledonian

University

University for the Common Good

\section{Green infrastructure as an adaptation approach to tackling urban overheating in the Glasgow Clyde Valley Region, UK}

Emmanuel, R.; Loconsole, A.

Published in:

Landscape and Urban Planning

DOI:

10.1016/j.landurbplan.2015.02.012

Publication date:

2015

Document Version

Author accepted manuscript

Link to publication in ResearchOnline

Citation for published version (Harvard):

Emmanuel, R \& Loconsole, A 2015, 'Green infrastructure as an adaptation approach to tackling urban overheating in the Glasgow Clyde Valley Region, UK', Landscape and Urban Planning, vol. 138, pp. 71-86. https://doi.org/10.1016/j.landurbplan.2015.02.012

\section{General rights}

Copyright and moral rights for the publications made accessible in the public portal are retained by the authors and/or other copyright owners and it is a condition of accessing publications that users recognise and abide by the legal requirements associated with these rights.

Take down policy

If you believe that this document breaches copyright please view our takedown policy at https://edshare.gcu.ac.uk/id/eprint/5179 for details of how to contact us. 
Green infrastructure as an adaptation approach to tackling urbanoverheating in the Glasgow Clyde Valley Region, UK

R. Emmanuel ${ }^{a^{*}}, A$. Loconsole $^{b}$

${ }^{a}$ School of Engineering \& Built Environment, Glasgow Caledonian University, UK

${ }^{b}$ Department of Material Sciences, University of Salento, Italy

\section{Citation:}

Emmanuel, R., \& Loconsole, A. Green infrastructure as an adaptation approach to tackling urban overheating in the Glasgow Clyde Valley Region, UK. Landscape Urban Plan. (2015), http://dx.doi.org/10.1016/j.landurbplan.2015.02.012 


\section{Highlights:}

- Classification of urban areas into local climate zones (LCZ)

- CFD simulation of green cover in mitigating climate change and heat island effects

- $20 \%$ increase in green cover could reduce surface temperatures by $2^{\circ} \mathrm{C}$ in 2050

- Green infrastructure option to achieve $20 \%$ increase in greenery are presented

\section{Abstract}

Although urban growth in the city of Glasgow, UK, has subsided, urban morphology continues to generate local heat islands. We present a relatively less data-intense method to classify local climate zones (LCZ) and evaluate the effectiveness of green infrastructure options in tackling the likely overheating problem in cold climate urban agglomerations such as the Glasgow Clyde Valley (GCV) region. LCZ classification uses LIDAR data available with local authorities, based on the typology developed by Stewart and Oke (2012). LCZ classes were then used cluster areas likely to exhibit similar warming trends locally. This helped to identify likely problem areas, a sub-set of which were then modelled for the effect of green cover options (both increase and reduction in green cover) as well as building density options.

Results indicate green infrastructure could play a significant role in mitigating the urban overheating expected under a warming climate in the GCV Region. A green cover increase of approximately $20 \%$ over the present level could eliminate a third to a half of the expected extra urban heat island effect in 2050. This level of increase in green cover could also lead to local reductions in surface temperature by up to $20 \mathrm{C}$. Over half of the street users would consider a $20 \%$ increase in green cover in the city centre to be thermally acceptable, even under a warm 2050 scenario. The process adopted here could be used to estimate the overheating problem as well as the effectiveness green infrastructure strategies to overcome them. 


\section{Introduction}

In the face of growing consensus on the anthropogenic causes for global climate change (see IPCC, 2013) and the lag-times involved in the mitigation of such changes, there is considerable focus on the enhancement of adaptive capacity of human systems to cope with climate change. Given the rapid rise in global urbanisation much of the adaptive action needs to occur in cities. However, research on the augmentation of climate change effects by local urban warming (characterised by urban heat islands) remains weak. A key difficulty in untangling the urban warming from global climate change is the computational and parametric difficulties associated with representing urban areas in climate models (Jin et al., 2005; Grawe et al., 2013). Additionally, translating future climate change projections at finer spatial scales relevant to cities typically use statistical downscaling techniques to global climate models without modelling the urban areas themselves (Lemonsu et al., 2013) a technique not without problems. Although the situation is continuing to improve (cf. Hebbert and Jankovic, 2013) much more still need to be done to (a) ameliorate the urban heat island (UHI) effect and (b) use UHI mitigation as part of climate change adaptation.

World's shrinking cities face additional problems in managing climate change. Previous work in Glasgow (Emmanuel and Kruger, 2012; Kruger et al., 2013) - one such 'shrinking city' - indicates that even when urban growth has subsided, the local warming that result from urban morphology (increased built cover, lack of vegetation, pollution, anthropogenic heat generation) continue to generate local heat islands. Such heat islands are of the same order of magnitude as the predicted warming due to climate change by 2050 . And the micro-scale variations are strongly related to local land cover/land use patterns. However, current climate change adaptation strategies are more focussed on reducing carbon emission than managing the change via land use / land cover manipulations, even though the latter is relatively easier to manage in shrinking cities. 
Given these realities, it is necessary to explore the role of land cover changes especially green infrastructure changes, as potential climate change adaptation options. Specifically, it is necessary to quantify the scale of green infrastructure changes needed in specific cities and explore ways to accomplish them. It in this light the present paper explores the role of green cover in areas of different urban density within the Glasgow Clyde Valley (GCV) Region in the central belt of Scotland. It characterises the urban pattern within the GCV in terms of their local warming attributes, using a classification system known as the Local Climate Zones (LCZ) (Stewart and Oke, 2012). Such classification could help identify areas most likely to experience significant overheating problem in the future (cf. Lelovics et al., 2014). Computational fluid dynamics (CFD) simulations are then carried out to test the applicability of green infrastructure approaches. Alternative strategies to enhance the green cover in a Glasgow city centre neighbourhood are presented.

The rest of the paper is structured in five sections: Section 2 presents background evidence to the presence of the heat island phenomenon in Glasgow and the two techniques commonly used to study it (local climate zones to classify urban areas and ENVI-met, a CFD model commonly used to study the effectiveness of mitigation strategies). Sections 3 and 4 detail the land cover/land use classification employed in the present study. Section 5 presents the results of the simulation exercise and Section 6 explores the implications of the results. It is hoped that the method of classifying LCZ using relatively easily available data as well as the exploration of green infrastructure in ameliorating the likely overheating problem could be applicable to other cold climate cities.

\section{Background}

\subsection{Glasgow's heat island phenomenon}

Based on a four-pronged approach to map the local climate variations in and around the city of Glasgow in 2011 (historic climate trends in the city; fixed weather station data in and around the city; microclimate variations at the street canyon level within the city core, and thermal perception 

found the following: term.

\subsection{Local Climate Zone classification} building/tree height and spacing, soil moisture, and anthropogenic heat flux. LCZ has 16 climate

1. Even when urban growth has subsided, the local warming that result from urban morphology (increased built cover, lack of vegetation, pollution, anthropogenic heat generation) continue to generate local heat islands;

2. Such heat islands are of the same order of magnitude as the predicted warming due to climate change to 2050;

3. Substantial variations within city neighbourhoods exist and these relate to land use/land cover attributes, pointing to planning possibilities to locally mitigate the negative consequences of overheating;

4. Strategies to tackle local overheating can lead to less carbon intensive enhancement of comfort, health and quality of life both within and outside buildings.

Given the geographic and urban growth similarities of the GCV region to that of the city of Glasgow, the overheating problem in the GCV area is likely to be similar. Carefully planned development of urban morphological variables such as the green infrastructure offers possibilities to enhance outdoor livability and reduced building energy use in the immediate future when the regional climate remains relatively similar to current conditions, but also provides an adaptive mechanism when the background climate continues to warm (Kleerekoper et al., 2012), thus lending itself to be a useful strategy to adapt to climate change in the GCV region, both in the immediate- and longIn order to characterise the land use / land cover patterns in areas of interest, we used the 'Local Climate Zone' (LCZ) system developed by Stewart and Oke (2012). LCZs are defined as 'regions of uniform surface-air temperature distribution at horizontal scales of $10^{2}$ to $10^{4}$ metres' (Stewart and Oke, 2012). Their definition is based on characteristic geometry and land cover that is expected to generate a unique near-surface climate under calm, clear skies. These include vegetative fraction, zones and the classification system has been validated in Sweden, Japan and Canada (Stewart and 
Oke, 2009) and widely used in other contexts (for example, Lelovics et al., 2014; Middel, et al., 2014; Villadiego and Velay-Dabat, 2014).

Although the LCZ classification system was not developed for mapping the UHI effect but to assist in the selection of locations for local weather stations and to report heat island effect in a standardised manner, it is a useful system to identify micro-climatically distinguishable areas within an urban agglomeration, and this aspect of the LCZ is useful in identifying the likely local warming effects of urban development. This was indeed shown to be true in Glasgow (see Figure 12 in Emmanuel and Kruger, 2012).

\subsection{CFD simulations in UHI studies}

The non-linearity of the $\mathrm{UHI}$ problem lends itself to numerical simulations and is therefore increasingly popular in urban climatology (Saneinejad et al, 2014). Urban microclimate models vary widely with regard to their physical basis and spatial/temporal resolution. Ali-Toudert \& Mayer (2006) provide a detailed critique of contemporary models at the micro-scale with fine temporal resolutions. They inferred that ENVI-met (Bruse 1999, 2004) is perhaps the only micro-scale computational fluid dynamic model that is capable of analyzing the thermal comfort regime within the street canyon at fine resolutions (down to $0.5 \times 0.5 \mathrm{~m}$ ). ENVI-met is increasingly being used to assess the effectiveness of urban planning measures to tackle the UHI problem in a variety of climate contexts (for example, Ketterer and Matzarakis, 2014 - Stuttgart, Germany; Chen and Ng, 2013 Hongkong SAR; Emmanuel et al., 2010 - Colombo, Sri Lanka; Middell et al., 2014 - Phoenix, USA; Skelhorn et al., 2014, Manchester, UK).

ENVI-met is a three-dimensional non-hydrostatic model for the simulation of surface-plant-air interactions, especially within the urban canopy layer. It is designed for the micro-scale with a typical horizontal resolution from 0.5 to $10 \mathrm{~m}$ and a typical time frame of 24 to $48 \mathrm{~h}$ with a time step of $10 \mathrm{~s}$. This resolution allows the investigation of small-scale interactions between individual buildings, surfaces and plants (Bruse 2004). 
Input meteorological data required to initiate ENVI-met simulations are: wind speed and direction at $10 \mathrm{~m}$ above ground, roughness length $\left(\mathrm{Z}_{\mathrm{o}}\right)$, initial temperature of the atmosphere, specific humidity at $2500 \mathrm{~m}$ and relative humidity at $2 \mathrm{~m}$. The model calculation includes surface and wall temperatures for each grid point and wall and the calculation of bio-meteorological parameters such as the Mean Radiant Temperature (MRT) or Predicted Mean Vote (PMV) (Fanger 1970).

A shortcoming of ENVI-met is that buildings, which are modelled as blocks where width and length are multiples of grid cells, have no thermal mass and have constant indoor temperature. Moreover, albedo and thermal transmission (U-value) for walls and roofs are the same for all buildings. However, it is an effective tool for the analysis of urban temperature at the micro-scale with fine temporal resolutions (Ali-Toudert \& Mayer, 2006).

\section{Method}

The pursuit of green infrastructure strategies to tackle the overheating problem due to climate change enhanced by local warming in the GCV required the following steps:

1. Identification of localities where local warming is likely to be the most intense (the "hot spots');

2. Estimation of the likely future climate (in 2050);

3. Evaluation of the sensitivity of green infrastructure-based adaptation options to reduce the 'hot spots' under future climate.

We classified the GCV region into LCZ classes using Ordnance Survey (OS) and LiDAR data to estimate surface characteristics such as building cover, building height, land cover and/or land use. Ordnance Survey is the UK's national mapping authority providing detailed land cover information and its data are available free of charge at: https://www.ordnancesurvey.co.uk. Vector files containing the following layers were downloaded for the National Grid No. NS26, which covers all of the GCV Region. More details on the National Grid are available at: 
contains land cover data for a $100 \times 100 \mathrm{~km}$ area. Light Detection And Ranging (LiDAR) data is an accurate, high resolution three-dimensional data used to create highly detailed digital surface models that could eventually be turned into three dimensional city models. LiDAR technology allows large area models to be created in a very short space of time. LiDAR data for the present study area was provided by the Glasgow Clyde Valley Green Network Partnership

(http://www.gcvgreennetwork.gov.uk/) which itself obtained the data from the local authorities in the GCV region. Additional ground truth verification of selected representative areas using 'Google Earth' and site visits helped verify building height and other physical parameters. Future climate data were obtained from the UK Climate Projections 2009 - UKCIP'09 (http://www.ukcip.org.uk/). UKCIP'09 is the fifth generation of climate change information for the UK and is based on inductive probability (i.e. estimations are based on the available information and strength of evidence instead of taking into account all the possible outcomes)

The evaluation of the effect of green infrastructure was carried out using ENVI-met simulations. Six scenarios were run as detailed below. : parks, street trees, green roofs, green walls, etc).

\subsection{Green Area Ratio (GAR) method}

Not all green areas contribute equally to local cooling nor are they equal in their other 
weighting systems that captures the relative environmental performance of different types of green cover. The most widely used among these is the Green Area Ratio (GAR) method (Keeley, 2011). GAR assigns weighting factors for different types of urban green infrastructure, based on their relative environmental performance in terms of climate change mitigation. It is currently implemented in Berlin and has been adapted in Malmo (Sweden), several cities in South Korea and Seattle (USA) (Keeley, 2011). Table 1 shows the relative weighting of different types of green cover.

\title{
4. Effect of land use / land cover and local climate
}

\author{
(Table 1 here)
}

The key to understanding the local climatic effect of land cover/land use characteristics is to classify the settlement area according to their key climate-influencing features.

\subsection{Site selection using the LCZ approach}

The following steps were performed to determine the dominant LCZ classes in the GCV region and thus select 'representative' sample locations where local warming is likely to be problematic.

1. Determine the 'developed' areas of the GCV

2. Calculate built fraction / natural cover within $1 \mathrm{~km}$ dia circles placed in an array covering the entire 'developed' area in the GCV identified in step 1

3. Classify each circle into relevant LCZ class, depending on built/green fraction and building height closely matching the urban morphological parameters shown in Table 2

4. Select sample locations representing the different LCZ classes available within the GCZ

(Table 2 here)

The aim of the first step was to reduce the area of enquiry to 'developed' areas within the urban agglomeration to limit the computational time needed. We first downloaded the data for the area of interest from the ordnance survey open database. The GCV Region covers only a small part of the $100 \times 100 \mathrm{~km}$ NS square (NS26, see Section 3), and the 'developed' area within the relevant NS square was clipped and a $1 \mathrm{~km} \times 1 \mathrm{~km}$ grid was placed over it. This resulted in 1519 grid points on the $1 \mathrm{~km} \times$ 
$1 \mathrm{~km}$ grid and a circle of $500 \mathrm{~m}$ in radius was added to each point to carry out Step 2. Step 2 then calculated the built cover (building footprints and roads) as well as the 'natural' cover. The building cover were divided into categories (depending on their three dimensional properties.

Step 3 (determination of the LCZ class of each $1 \mathrm{~km}$ dia. Circle) was carried out as follows: Four small circles (500m dia.) were created within each large circle (See Figure 1 ). The percentages of buildings, roads, inland water and natural cover were calculated for each of the $500 \mathrm{~m}$ dia. circles using ArcGIS (v.10.1) and averaged to derive at the land cover types for each of the $1 \mathrm{~km}$ radius circle. Figure 2 shows the results of Step 3.

(Figure 1 here)

(Figure 2 here)

It could be seen from Figure 2 that the GCV region largely composes of two classes of 'semi-dense' urban morphology (LCZ 2 and 3 - Compact midrise, mainly Glasgow City centre) and three classes of 'sparse' settlement morphology (LCZ 5 - Open midrise; LCZ 6 - Open lowrise; LCZ 9 - Sparsely built).

Based on these results Step 4 selected six sites. In addition to representing the variations in LCZ classes this step also considered the location of local weather stations, the data from which could be useful in initiating the ENVI-met model runs for each of the selected sites. The selected sites are listed below (See Figure 3 for locations and Figure 4 for three-dimensional details):

1-2. LCZ 2 - Compact midrise two locations characterising this class: Glasgow City Centre West (Gla CCW) centred on the intersection of W Campbell Street \& Bath Street (Coordinates - British National Grid; map projection: transverse Mercator; datum: OSGB: 36258595.665 - 665800.603 Meters) and Glasgow City Centre East (Gla CCE) comprising an area surrounding the George Square area, centred on the intersection of John Street \& Ingram Street (259339.524 - 665260.852 Meters);

3. LCZ 6 - Open lowrise: Clyde Gateway area (London Road \& Springfield Road) (260683.157 -663742.061 Meters);

4. LCZ 5 - Open midrise: Paisley area (High Street \& New Street) (248146.997 - 663988.741 Meters) 


\section{Simulation of the effects of green infrastructure in the GCV}

The performance of ENVI-met was validated for Glasgow, using a process described by Loconsole (2013). We used data from a weather station set up on the city campus of Glasgow Caledonian University $\left(55.86611^{\circ} \mathrm{N}, 4.25^{\circ} \mathrm{W}\right)$ for this purpose. For the turbulence closure of the atmospheric

5-6. LCZ 9 - Sparsely built (or extensive lowrise): two locations characterising this class Wishaw (Caledonia Rd. and Main St.) (279691.562 - 655018.654 Meters), and Hamilton (Brandon St. and Quarry St.) (272438.576 - 655517.511 Meters)

(Figure 3 here)

(Figure 4 here)

Land cover characteristics of the individual sites are shown in Figures 5-9 (Note Sites 1 and 2 are covered by Figure 5). Each figure shows the land cover as given in the Ordnance Survey maps (see 'Legend' at bottom left). These were amalgamated into categories relevant to LCZ (bottom right) as follows:

Built cover = Building, Structure, Structure on path, Glasshouse;

Natural = Natural Environment, Natural Environment along road or track;

Transportation $=$ Road or Track, Roadside, Rail, Path

Water $=$ Tidal Water, Inland Water

Open Surface $=$ General Surface

Unclassified = Landform, Unclassified, Landform along road/track

(Figure 5 here)

(Figure 6 here)

(Figure 7 here)

(Figure 8 here)

(Figure 9 here) 
the upper boundary employed the prognostic 1.5 order $\kappa-\varepsilon$ closure model and $\kappa-\varepsilon$ closed model

(fixed value) respectively. The lateral boundary conditions for both temperature and humidity as well as Total Kinetic Energy are set as open so the values of the next grid point close to the border are copied to the border at each time step.

We performed several ENVI-met model runs to derive appropriate input parameters. Table 3 shows the changes made to input parameters, domain size, grid size etc. With regard to the computational domain and the grid size, two settings were tested during the setup process: $80 \times 80 \times 30$ grids (grid size $=5 \mathrm{~m} \times 5 \mathrm{~m} \times 3 \mathrm{~m}$ ) resulting in a $400 \mathrm{~m} \times 400 \mathrm{~m}$ domain and $80 \times 80 \times 30$ grids (grid size $=20 \mathrm{~m} \times 20 \mathrm{~m} \times$ $3 \mathrm{~m}$ ) resulting in a $1600 \mathrm{~m} \times 1600 \mathrm{~m}$ domain. The first domain size was chosen taking into account the minimum LCZ spatial definition while the second accounted for the maximum LCZ spatial definition. However, given the extremely time consuming nature of the simulation of the larger domain (over 100 hrs per simulation) it was decided to use the $400 \mathrm{~m} \times 400 \mathrm{~m}$ domain throughout the present work.

Figure 10a shows the results of simulated and measured temperatures in the city of Glasgow on 30 April 2011. Figure $10 \mathrm{~b}$ shows the comparison for the daytime (06:00 -18:00 hrs) (Root Mean Square Error $[\mathrm{RMSE}]=0.83$ and $\left.\mathrm{R}^{2}=0.9461\right)$. This compares well with the results of Skelhorn et al., (2014) for Manchester where the correlation between the measured and modelled temperatures during 09:00-midnight were $R^{2}=0.9393$. Figure $10 \mathrm{~b}$ also indicates that the model over-predicts during the nighttime and under-predicts during the day. Given the use of the model in the present paper (comparison of cooling effects of green infrastructure during the day) this limitation is therefore likely to err on the conservative side. 


\subsection{Air temperature effects}

269

During the daytime the different green cover scenarios result in little variation in air temperature while the suburban/rural sites show marked decrease in air temperature at increased levels of green cover (Figure 11). The situation at nighttime (Figure 12) is different, in that there is a consistent pattern of cooling at all sites.

(Figure 11 here)

(Figure 12 here)

Figure 13 shows the average cooling expected over the course of summer in 2050. The overall effect of green cover on air temperature under future climate scenario is encouraging.

(Figure 13 here)

Figure 14 shows the level at which green cover makes the most impact is approx. $20 \%$ above the current level, with diminishing returns thereafter. At this level of green cover a net cooling of $0.3^{\circ} \mathrm{C}$ can be expected in 2050. This would be about a third of the extra heat island effect predicted for the Glasgow conurbation (Kershaw et al., 2010).

(Figure 14 here)

The range in temperature change due to green cover change across the entire simulated domain (400m $\times 400 \mathrm{~m}$ area) is tabulated Table 4. A vast majority of pixels - i.e. to $91.2 \%$ (Glasgow City Centre) $-99.8 \%$ (Wishaw) of the simulated area - showed up to $0.5^{\circ} \mathrm{C}$ reduction in air temperature. Based on the expected heat island effect for the Glasgow area this local cooling effect would be more than half of the total urban warming expected in 2050. The case of Gla CC-E (around George Square) is interesting, in that the lack of green cover increase could lead to $19 \%$ of the area showing a slight increase (up to $0.25^{\circ} \mathrm{C}$ ) in temperature under the 2050 base case scenario. 


\subsection{Surface temperature effects}

291

292

293

294

295

296

297

298

299

300

301

302

303

304

\subsection{Thermal comfort implications of green cover}

305

306

307

308

309

310 increased green cover (suburban sites).

(Figure 15 here)

(Figure 16 here) $\mathrm{Cfb})$.

In addition to calculating air temperatures, ENVI-met also produces surface temperatures within the model domain area (Figure 15 [daytime] and Figure 16 [nighttime]). There is a marked decrease especially during the day and in conjunction with increased shading/green cover (city centre sites) or

While surface temperatures are particularly susceptible to the vagaries of local shading (or lack thereof) the purpose here was to compare results with that of other UK cities, most notably Manchester (Gill et al., 2007) where a 10-20\% increase in green cover led to up to $4^{\circ} \mathrm{C}$ decrease in surface temperature while green roofs in city centre led to a lowering of surface temperature by up to $6^{\circ} \mathrm{C}$. Given the influence of surface temperature on the Mean Radiant Temperature ( $\left.\mathrm{T}_{\mathrm{MRT}}\right)$ it is also noteworthy that Klemm et al (2015) found a $1 \mathrm{~K}$ drop in $\mathrm{T}_{\mathrm{MRT}}$ for a $10 \%$ increase in street tree cover in Utrecht, Netherlands - whose climate is similar to that of Glasgow (Köppen classification =

A commonly used measure of human thermal perception is the Predicted Mean Vote (PMV), based on BS EN ISO 7730 (2005). PMV is a 'comfort vote' on a 7-point scale that takes into account environmental factors such as air temperature, relative humidity, air velocity and MRT as well as personal attributes such as clothing and level of activity. Although PMV was originally developed for the estimation of indoor comfort previous work (Kruger et al., 2012) found it had good agreement with street users' subjective thermal sensation in Glasgow's outdoors $\left(R^{2}=0.987\right)$. 
ISO 7730 specifies a range of -1.0 to +1.0 within which approximately $75 \%$ of the subjects would be 'satisfied' with their thermal environment.

Based on ISO 7730 (i.e. a 'comfort vote' between -1.0 to +1.0 is acceptable to a majority of street users) $52.5-54.6 \%$ of the users in city centre would consider 2050 climate acceptable if a $20 \%$ increase in green cover could be provided (Table 5). However $36.6-40 \%$ of the users in the city centre will still feel 'hot' under such a scenario. A combination of $20 \%$ greenery with tall buildings in the city centre (not shown in the present paper) would lead to $72.8-86 \%$ of the users feeling comfortable (Table 6). In suburban and less built up areas however, Tables 3 and 4 indicate the thermal comfort effect of green cover will be more muted. A $100 \%$ increase in green cover will be required to make significant improvement in perceived thermal comfort in three of the four less built up sites (Paisley, Clyde Gateway and Hamilton).

\section{Implications and Conclusions}

The simulation work carried out by the present study indicates that green infrastructure could play a significant role in mitigating the urban overheating expected under a warming climate in the GCV Region. Our work also indicates that a green cover increase of approximately $20 \%$ over the present level could eliminate a third to a half of the expected extra urban heat island effect in 2050 . This level of increase in green cover could also lead to local reductions in surface temperature by up to $2^{\circ} \mathrm{C}$. Furthermore, over half of the street users would consider a $20 \%$ increase in green cover in the city centre to be thermally acceptable, even under a warm 2050 scenario. Additional strategies such as increased building cover could further improve the thermal comfort and air temperature patterns in the city centre. 


\subsection{Achieving green cover increase - an example}

333

334

In practical terms a $20 \%$ increase in green cover could be achieved in a number of different ways: mini-parks, street trees, grass areas, roof gardens, green walls or even urban forests. We used the GAR method (See section 3.1) to develop alternate arrangements that could achieve a $20 \%$ increase in green cover.

Table 7 here

Table 7 shows the assumptions made and the method used in attempting to deliver a $20 \%$ increase in green cover in Glasgow city centre, using green parks, street trees, green roofs, green façade or a combination of these. Based on these the following fractions of green cover are possible in the Gla CC-W domain area (all fractions expressed as percentage of the total simulated domain area):

Current green cover $=3.3 \%$

Possible street tree cover $=3.72 \%$

Possible roof area available for roof garden $=21 \%$

Possible façade cover available $=6.34 \%$

(Table 8 here)

Table 8 shows some options to achieve $20 \%$ green cover increase at the Glasgow city centre west (Gla. CC-W) site using the weightings shown in Table 1 . These range from introducing a $1,056 \mathrm{~m}^{2}$ $(32.5 \mathrm{~m} \times 32.5 \mathrm{~m})$ park to planting up to 528 new street trees to extensive roof gardens up to $1,056 \mathrm{~m}^{2}$ or introducing $1,268 \mathrm{~m}^{2}$ of green façade at this site.

The amelioration of urban heat island has a long pedigree and cities have adapted to local warming for a very long time (cf. Hebbert and Jankovic, 2013). Green infrastructure is long known to have a positive impact on the minimisation of the UHI effect (Gill et al., 2007). The present work shows an easy-to-use method to classify the urban landscape into Local Climate Zones and then to use this to 

expected overheating problem under a changing climate in the GCV. The extent of green cover necessary to make a cooling impact is modest, and there are several options to achieve this. More work will be needed to evaluate the relative merits of specific green infrastructure interventions at specific urban sites. Furthermore, urban governance mechanisms (Foo et al., 2015) and institutional

overcome the urban overheating problem expected under a warming climate.

\section{References}

Ali Toudert F, Mayer H. 2006. Numerical study on the effects of aspect ratio and orientation of an urban street canyon on outdoor thermal comfort in hot and dry climate, Building \& Environment, 41, pp. 94-108

Bruse M. 2011. ENVI-met Model Homepage. http://www.envi-met.com

BS EN ISO 7730, 2005. Ergonomics of the thermal environment - Analytical determination and interpretation of thermal comfort using calculation of the PMV and PPD indices and local thermal comfort criteria

Chen $\mathrm{L}, \mathrm{Ng}$ E. 2013. Simulation of the effect of downtown greenery on thermal comfort in subtropical climate using PET index: a case study in Hong Kong, Architectural Science Review, 56, pp. 297-305

David Grawe D, Thompson HL, Salmond JA, Cai X.-M, Schlünzen KH. 2013. Modelling the impact of urbanisation on regional climate in the Greater London Area, Int. J. Climatol. 33, pp. 2388-2401

Emmanuel R, Krüger E. 2012. Urban Heat Island and its impact on climate change resilience in a shrinking city: the case of Glasgow, UK. Building and Environment, 53, pp. 137-149

Fahmy M, Sharples S. 2009. On the development of an urban passive thermal comfort system in Cairo, Egypt. Building and Environment, 44, pp. 1907-1916

Fanger PO. 1970. Thermal Comfort: Analysis \& Applications in Environmental Engineering. McGraw-Hill, New York

Foo KE, McCarthy J, Bebbington A. 2015. A framework for governing urban green infrastructure, Landscape and Urban Planning, this volume/issue

Gill SE, Handley JF, Ennos AR, Pauleit S. 2007. Adapting cities for climate change: the role of the green infrastructure, Built Environment, 33, pp. 115-133

Hebbert M, Jankovic V. 2013. Cities and climate change: the precedents and why they matter, Urban Studies, 50, pp. 1332-1347

Jin M, Dickinson RE, Zhang D.-L. 2005. The Footprint of Urban Areas on Global Climate as Characterized by MODIS. Journal of Climate, 18, pp. 1551-1565

Keeley M. 2011. The Green Area Ratio: an urban site sustainability metric. Journal of Environmental Planning and Management, 54, pp. 937-958

Kershaw T, Sanderson M, Coley D, Eames M. 2010. Estimation of the urban heat island for UK climate change projections, Building Serv. Eng. Res. Technol., 31, pp. 251-263. DOI: 10.1177/0143624410365033 
Ketterer C, Andreas Matzarakis A. 2014. Human-biometeorological assessment of heat stress reduction by replanning measures in Stuttgart, Germany, Landscape and Urban Planning, 122, pp. 78-88

Kleerekoper L, van Esch M, Salcedo TB. 2012. How to make a city climate-proof, addressing the urban heat island effect. Resources, Conservation and Recycling, 64, pp. 30- 38

Klemm W, Heusinkveld BG, Lenzholzer S, Van Hove B. 2015. Street greenery and its physical and psychological impact on outdoor thermal comfort, Landscape and Urban Planning, this volume/issue

Krüger E, Drach P, Emmanuel R, Corbella O. 2013. Urban heat island and differences in outdoor comfort levels in Glasgow, UK. Theoretical \& Applied Climatology, 112, pp. 127-141

Lelovics E, Unger J, Gal T. 2013. Design of an urban monitoring network based on Local Climate Zone mapping and temperature pattern modelling, Climate Research, 60, pp. 51-62

Lemonsu A, Kounkou-Arnaud R, Desplat J, Salagnac J.-L, Masson V. 2013. Evolution of the Parisian urban climate under a global changing climate, Climatic Change, 116, pp. 679-692

Loconsole A. 2013. Modelling of the Urban Heat Island in the Clyde Valley Region (Scotland) and future green mitigation strategies, MSc Thesis, University of Salento, Italy

Matthews T, Lo AY, Byrne J. 2015. Reconceptualizing green infrastructure for climate change adaptation: Barriers to adoption and drivers for uptake by spatial planners, Landscape and Urban Planning, this volume/issue

Middel A, Häb K, Brazel AJ, Martin CA, Guhathakurta S. 2014. Impact of urban form and design on midafternoon microclimate in Phoenix Local Climate Zones, Landscape and Urban Planning, 122, pp. 16-28

Saneinejad S, Moonen P, Carmeliet J. 2014. Comparative assessment of various heat island mitigation measures, Building and Environment, 73, pp. 162-170

Skelhorn C, Lindley S, Levermore G. 2014. The impact of vegetation types on air and surface temperatures in a temperate city: A fine scale assessment in Manchester, UK, Landscape and Urban Planning, 121, pp. $129-140$

Stewart ID, Oke TR. 2012. Local Climate Zones (LCZ) for urban temperature studies. Bulletin of American Meteorological Society. 93, pp 1879-1900

Villadiego K, Velay-Dabat MA. 2014. Outdoor thermal comfort in a hot and humid climate of Colombia: A field study in Barranquilla, Building and Environment, 75, pp 142-152

Wong NH, Jusuf SK, Win AAL, Thu HK, Negara TS, Xuchao W. 2007. Environmental study of the impact of greenery in an institutional campus in the tropics. Building and Environment, 42, pp 2949-2970 


\section{List of Tables}

Table 1: Relative environmental performance weightings for different green infrastructure (Source: Based on Keeley 2011)

Table 2: Properties of Local Climate Zone (LCZ)

Table 3: Comparison of ENVI-met initial and final values

Table 4: Range of air temperature changes across the simulated domains

Table 5: Predicted Mean Vote (PMV) due to a 20\% increase in green cover in 2050

Table 6: 'Best' outcome in Predicted Mean Vote (PMV) in 2050

Table 7: Assumptions and calculation method to derive green infrastructure options for Gla CC-W

Table 8: Alternative approaches to increasing green cover by $20 \%$ in Gla. CC-W 
Table 1: Relative environmental performance weightings for different green infrastructure

Source: Based on Keeley 2011

\begin{tabular}{|c|c|c|}
\hline Technique / cover type & Rating & Description \\
\hline Impermeable surfaces & 0.0 & $\begin{array}{l}\text { Surfaces that do not allow the infiltration of } \\
\text { water. Includes: roof surfaces, concrete, } \\
\text { asphalt and pavers set upon impermeable } \\
\text { surfaces or with sealed joints }\end{array}$ \\
\hline $\begin{array}{l}\text { Impermeable surfaces, } \\
\text { from which all stormwater } \\
\text { is infiltrated on property }\end{array}$ & 0.2 & $\begin{array}{l}\text { Includes surfaces that are disconnected from } \\
\text { the sewer system. Collected water is instead } \\
\text { allowed to infiltrate on site in a swale or rain } \\
\text { garden. Guidelines for preventing } \\
\text { groundwater and soil contamination must be } \\
\text { followed }\end{array}$ \\
\hline $\begin{array}{l}\text { Non-vegetated, semi- } \\
\text { permeable surfaces }\end{array}$ & 0.3 & $\begin{array}{l}\text { Cover types that allow water infiltration, but } \\
\text { do not support plant growth. Example include: } \\
\text { brick, pavers and crushed stone }\end{array}$ \\
\hline $\begin{array}{l}\text { Vegetated, semi-permeable } \\
\text { surfaces }\end{array}$ & 0.5 & $\begin{array}{l}\text { Cover types that allow water infiltration and } \\
\text { integrate vegetation such as grass. Examples } \\
\text { include: wide-set pavers with grass joints, grass } \\
\text { pavers and gravel-reinforced grassy areas }\end{array}$ \\
\hline Green façades & 0.5 & $\begin{array}{l}\text { Vines or climbing plants growing (often from } \\
\text { ground) on training structures such as trellises } \\
\text { which are attached to a building. The façade's } \\
\text { area is measured as the vertical area the } \\
\text { selected species could cover after } 10 \text { years of } \\
\text { growth up to a height of } 10 \mathrm{~m} \text {; window areas } \\
\text { are subtracted from the calculation }\end{array}$ \\
\hline Extensive green roofs & 0.5 & $\begin{array}{l}\text { Green roofs with substrate/soil depths of less } \\
\text { than } 80 \mathrm{~cm} \text {. However, Berlin excludes green } \\
\text { roofs constructed on high-rise buildings }\end{array}$ \\
\hline $\begin{array}{l}\text { Intensive green roofs and } \\
\text { areas underlain by shallow } \\
\text { subterranean structures }\end{array}$ & 0.7 & $\begin{array}{l}\text { Green roofs with substrate/soil depths of } \\
\text { greater than } 80 \mathrm{~cm} \text {. This category includes } \\
\text { subterranean garages }\end{array}$ \\
\hline Vegetated areas & 1.0 & $\begin{array}{l}\text { Areas which allow unobstructed infiltration of } \\
\text { water without evaluation of the quality or type } \\
\text { of vegetation present. Examples range from } \\
\text { lawn to gardens and naturalistic wooded areas }\end{array}$ \\
\hline
\end{tabular}


Table 2: Properties of Local Climate Zone (LCZ)

\begin{tabular}{|c|c|c|c|c|c|c|c|c|}
\hline \multirow{2}{*}{$\begin{array}{l}\text { Local Climate } \\
\text { Zone (LZC) }\end{array}$} & \multicolumn{8}{|c|}{ Zone Properties } \\
\hline & $\Psi_{\text {sky }}$ & $\mathrm{H}: \mathrm{W}$ & SF & $\overline{Z_{H}}$ & $\mathbf{R C}$ & $\alpha$ & $\left(\mathrm{J} \mathrm{m}^{-2} \mathrm{~s}^{\frac{\mu}{1 / 2}} \mathrm{~K}^{-1}\right)$ & $\begin{array}{c}Q_{F} \\
\left(W m^{-2}\right)\end{array}$ \\
\hline Compact Highrise & $0.25-0.45$ & $>2$ & $>90 \%$ & $>35 m$ & 8 & $\begin{array}{l}0.12- \\
0.18\end{array}$ & $\begin{array}{l}1,200- \\
1,700\end{array}$ & $100-150$ \\
\hline Open-set Highrise & $0.40-0.70$ & $\begin{array}{l}0.75- \\
1.25\end{array}$ & $\begin{array}{l}50- \\
75 \%\end{array}$ & $>30 m$ & $7-8$ & $\begin{array}{l}0.12- \\
0.20\end{array}$ & $\begin{array}{l}1,200- \\
1,700\end{array}$ & $20-35$ \\
\hline Compact Midrise & $0.30-0.60$ & $\begin{array}{l}0.75- \\
1.25\end{array}$ & $>90 \%$ & $\begin{array}{l}15- \\
25 m\end{array}$ & $6-7$ & $\begin{array}{l}0.15- \\
0.20\end{array}$ & $\begin{array}{l}1,200- \\
2,000\end{array}$ & $30-40$ \\
\hline Open-set Midrise & $0.80-0.90$ & $\begin{array}{l}0.20- \\
0.30\end{array}$ & $\begin{array}{l}30- \\
50 \%\end{array}$ & $\begin{array}{l}10- \\
25 \mathrm{~m}\end{array}$ & $5-6$ & $\begin{array}{l}0.15- \\
0.20\end{array}$ & $800-1,500$ & $<10$ \\
\hline Compact Lowrise & $0.30-0.50$ & $\begin{array}{l}1.00- \\
1.50\end{array}$ & $>80 \%$ & $3-10 m$ & 6 & $\begin{array}{l}0.12- \\
0.20\end{array}$ & $\begin{array}{l}1,200- \\
1,500\end{array}$ & $25-35$ \\
\hline Open-set Lowrise & $0.55-0.75$ & $\begin{array}{l}0.50- \\
0.75\end{array}$ & $\begin{array}{l}45- \\
65 \%\end{array}$ & $3-10$ & $5-6$ & $\begin{array}{l}0.10- \\
0.20\end{array}$ & $700-1,700$ & $10-15$ \\
\hline Dispersed Lowrise & $>0.90$ & $\begin{array}{l}0.10- \\
0.20\end{array}$ & $\begin{array}{l}20- \\
30 \%\end{array}$ & $3-7 m$ & $5-6$ & $\begin{array}{l}0.10- \\
0.20\end{array}$ & $800-2,000$ & $<10$ \\
\hline $\begin{array}{l}\text { Lightweight } \\
\text { Lowrise }\end{array}$ & $0.30-0.50$ & $\begin{array}{l}1.00- \\
1.50\end{array}$ & $\begin{array}{l}70- \\
90 \%\end{array}$ & $2-4 m$ & $4-5$ & $\begin{array}{l}0.10- \\
0.20\end{array}$ & $600-1,000$ & $<5$ \\
\hline Extensive Lowrise & $>0.90$ & $<0.25$ & $>80 \%$ & $3-10 m$ & 5 & $\begin{array}{l}0.15- \\
0.25\end{array}$ & $\begin{array}{l}1,200- \\
1,500\end{array}$ & $30-50$ \\
\hline $\begin{array}{l}\text { Industrial } \\
\text { Processing }\end{array}$ & $0.70-0.90$ & $0.2-0.5$ & $45-65$ & $5-10 m$ & $5-6$ & $\begin{array}{l}0.12- \\
0.20\end{array}$ & $\begin{array}{l}1,500- \\
3,000\end{array}$ & $>200$ \\
\hline
\end{tabular}

$\Psi_{\text {sky }}=$ Sky View Factor; $\mathrm{H}: \mathrm{W}=$ building height to width ratio; $\mathrm{SF}=$ building surface fraction; $\mathrm{Z}_{\mathrm{H}}=$ roughness height; $\mathrm{RC}=$ terrain roughness class; $\mu=$ thermal admittance; $Q_{F}=$ anthropogenic heat flux 
Table 3: Comparison of ENVI-met initial and final values

\begin{tabular}{|c|c|c|c|}
\hline $\begin{array}{l}\text { ENVI-met model } \\
\text { section }\end{array}$ & Parameter & Initial value & Final value \\
\hline \multicolumn{4}{|l|}{ Main data } \\
\hline & Domain size & $1600 \mathrm{~m} \times 1600 \mathrm{~m}$ & $400 \mathrm{~m} \times 400 \mathrm{~m}$ \\
\hline & Grid size & $\begin{array}{l}20 m \text { (horizontal) } \\
\text { and } 3 m \text { (vertical) }\end{array}$ & $\begin{array}{l}5 \mathrm{~m} \text { (horizontal) } \\
\text { and } 3 \mathrm{~m} \text { (vertical) }\end{array}$ \\
\hline & Simulated day & $30 / 04 / 2011$ & $30 / 04 / 2011$ \\
\hline & Wind speed $(\mathrm{m} / \mathrm{s})$ & 6.2 & 4 \\
\hline & Wind direction & 270 & 247 \\
\hline & Roughness length (m) & 0.1 & 0.1 \\
\hline & Initial temperature of atmosphere $(\mathrm{K})$ & 283 & 292.39 \\
\hline & Relative humidity (\%) & 75 & 70 \\
\hline \multicolumn{4}{|l|}{ Timing } \\
\hline & Update surface data interval (s) & 30 & 30 \\
\hline & Update wind and turbulence interval (s) & 900 & 900 \\
\hline & Update radiation and shadows interval (s) & 600 & 600 \\
\hline & Update plant data interval (s) & 600 & 600 \\
\hline \multicolumn{4}{|c|}{ Lateral Boundary Condition (LBC) types } \\
\hline & LBC for Temperature and humidity & open & Open \\
\hline & LBC for Total Kinetic Energy & forced & Open \\
\hline \multicolumn{4}{|l|}{ Building } \\
\hline & Inside temperature $(\mathrm{K})$ & 293 & 293 \\
\hline & Heat Transmission Walls (W/m² $\mathrm{K})$ & 1.94 & 1.94 \\
\hline & Heat Transmission Roofs $\left(\mathrm{W} / \mathrm{m}^{2} \mathrm{~K}\right)$ & 6 & 2.5 \\
\hline & Albedo walls & 0.2 & 0.6 \\
\hline & Albedo roofs & 0.3 & 0.6 \\
\hline \multicolumn{4}{|l|}{ Soil data } \\
\hline & Initial temp. upper layer $(0-20 \mathrm{~cm})(\mathrm{K})$ & 293 & 286 \\
\hline & Initial temp. middle layer $(20-50 \mathrm{~cm})(\mathrm{K})$ & 293 & 281 \\
\hline & Initial temp. lower layer $(>50 \mathrm{~cm})(\mathrm{K})$ & 293 & 276 \\
\hline & Rel. humidity upper layer $(0-20 \mathrm{~cm})(\mathrm{K})$ & 50 & 50 \\
\hline & Rel. humidity middle layer $(20-50 \mathrm{~cm})(\mathrm{K})$ & 60 & 60 \\
\hline & Rel. humidity lower layer $(>50 \mathrm{~cm}$ ) & 60 & 70 \\
\hline \multicolumn{4}{|l|}{ Timesteps } \\
\hline & Sun height for switching dt(0) & 40 & 40 \\
\hline & Sun height for switching dt(1) & 50 & 50 \\
\hline & Time step (s) for interval $1 \mathrm{dt}(0)(\mathrm{s})$ & 10 & 10 \\
\hline & Time step (s) for interval $2 \mathrm{dt}(1)(\mathrm{s})$ & 5 & 5 \\
\hline & Time step (s) for interval $3 \mathrm{dt}(2)(\mathrm{s})$ & 2 & 2 \\
\hline \multicolumn{4}{|l|}{ Turbulence } \\
\hline & Turbulence Closure ABL & prognostic & Prognostic \\
\hline
\end{tabular}




\begin{tabular}{|lll|}
\hline Turbulence Closure 3D Model & prognostic & Prognostic \\
\hline Upper Boundary for e-epsilon & closed & Closed \\
\hline
\end{tabular}


Table 4: Range of air temperature changes across the simulated domains

\begin{tabular}{|c|c|c|c|c|c|c|}
\hline & Gla CC-W & Gla CC-E & Paisley & $\begin{array}{c}\text { Clyde } \\
\text { Gateway }\end{array}$ & Wishaw & Hamilton \\
\hline \multicolumn{7}{|l|}{$<-1.00$} \\
\hline-1.00 to -0.75 & & & & $0.2 \%$ & & \\
\hline-0.75 to -0.50 & & & & $0.6 \%$ & $0.1 \%$ & $0.4 \%$ \\
\hline-0.50 to -0.25 & $0.3 \%$ & & $1.8 \%$ & $1.9 \%$ & $3.2 \%$ & $2.6 \%$ \\
\hline-0.25 to 0.00 & $90.9 \%$ & $81.0 \%$ & $94.6 \%$ & $93.3 \%$ & $96.6 \%$ & $95.9 \%$ \\
\hline 0.00 to +0.25 & $8.8 \%$ & $19.0 \%$ & $3.1 \%$ & $4.1 \%$ & $0.0 \%$ & $1.1 \%$ \\
\hline+0.25 to +0.50 & & & $0.5 \%$ & & & $0.1 \%$ \\
\hline+0.50 to +0.75 & & & $0.0 \%$ & & & \\
\hline \multicolumn{7}{|l|}{+0.75 to +1.00} \\
\hline$>+1.00$ & & & & & & \\
\hline
\end{tabular}


Table 5: Predicted Mean Vote (PMV) due to a $20 \%$ increase in green cover in 2050

\begin{tabular}{lllllll}
\hline & Gla CC - W & Gla CC - E & Paisley & $\begin{array}{l}\text { Clyde } \\
\text { Gateway }\end{array}$ & Wishaw & Hamilton \\
\hline$<-2.0$ & & & & \\
\hline-2.0 to -1.5 & & & & & & $2.0 \%$ \\
\hline-1.5 to -1.0 & & & $0.7 \%$ & & $1.4 \%$ & $8.9 \%$ \\
\hline-1.0 to -0.5 & & & $7.7 \%$ & $1.0 \%$ & $11.9 \%$ & $19.1 \%$ \\
\hline-0.5 to 0.0 & $4.9 \%$ & $3.6 \%$ & $31.1 \%$ & $20.4 \%$ & $9.2 \%$ & $8.4 \%$ \\
\hline 0.0 to +0.5 & $31.8 \%$ & $35.6 \%$ & $12.5 \%$ & $8.4 \%$ & $2.1 \%$ & $5.4 \%$ \\
\hline+0.5 to 1.0 & $15.8 \%$ & $15.4 \%$ & $5.8 \%$ & $3.9 \%$ & $18.7 \%$ \\
\hline+1.0 to +1.5 & $0.6 \%$ & $2.1 \%$ & $15.3 \%$ & $15.3 \%$ & $9.6 \%$ & $34.9 \%$ \\
\hline+1.5 to +2.0 & $7.0 \%$ & $6.8 \%$ & $24.6 \%$ & $44.2 \%$ & $57.6 \%$ & $2.6 \%$ \\
\hline$>2.0$ & $40.0 \%$ & $36.6 \%$ & $2.5 \%$ & $6.8 \%$ & $8.2 \%$ & \\
\hline
\end{tabular}

Table 6: 'Best' outcome in Predicted Mean Vote (PMV) in 2050

$\begin{array}{llll}\text { Gla CC }-W^{*} \quad \text { Gla CC - E* Paisley** } & \begin{array}{l}\text { Clyde } \\ \text { Gateway** }\end{array} & \text { Wishaw** Hamilton** } \\ & \end{array}$

$$
\begin{gathered}
<-2.0 \\
\hline-2.0 \text { to }-1.5
\end{gathered}
$$

\begin{tabular}{cllllll}
\hline-1.5 to -1.0 & & & $1.2 \%$ & $0.1 \%$ & & $3.3 \%$ \\
\hline-1.0 to -0.5 & & $0.0 \%$ & $14.4 \%$ & $8.1 \%$ & $7.1 \%$ & $18.2 \%$ \\
\hline-0.5 to 0.0 & $3.6 \%$ & $5.2 \%$ & $42.0 \%$ & $36.1 \%$ & $19.3 \%$ & $29.7 \%$ \\
\hline 0.0 to +0.5 & $48.8 \%$ & $42.9 \%$ & $14.5 \%$ & $6.2 \%$ & $9.2 \%$ & $8.0 \%$ \\
\hline+0.5 to 1.0 & $33.6 \%$ & $24.7 \%$ & $6.9 \%$ & $3.8 \%$ & $4.0 \%$ & $9.8 \%$ \\
\hline+1.0 to & $1.2 \%$ & $1.5 \%$ & $9.6 \%$ & $14.7 \%$ & $13.8 \%$ & $14.8 \%$
\end{tabular}

\begin{tabular}{ccccccc}
+1.5 & & & & & & \\
\hline+1.5 to & $3.6 \%$ & $2.4 \%$ & $10.6 \%$ & $30.4 \%$ & $44.1 \%$ & $16.0 \%$
\end{tabular}

\begin{tabular}{lllllll}
+2.0 & & & & & & \\
\hline$>2.0$ & $9.2 \%$ & $23.4 \%$ & $0.8 \%$ & $0.6 \%$ & $2.5 \%$ & $0.2 \%$ \\
\hline
\end{tabular}

Notes:

'Best' PMV outcomes are reached as follows:

* $-20 \%$ increase in green cover with Tall buildings (two city centre sites)

** $-100 \%$ increase in green cover (all the other four sites) 
Table 7: Assumptions and calculation method to derive green infrastructure options for Gla CC-W

\begin{tabular}{|c|c|c|c|}
\hline & Parameter & Quantity & Remarks \\
\hline 1 & Current green cover & $3.3 \%$ & Measured from GIS maps \\
\hline 2 & Total area of the simulation domain & $160,000 \mathrm{~m}^{2}$ & $400 \mathrm{~m} \times 400 \mathrm{~m}$ \\
\hline 3 & Available sidewalk & $11.15 \%$ & $\begin{array}{l}\text { Measured from GIS maps } \\
\text { (assumes average sidewalk } \\
=2 \mathrm{~m} \text { wide) }\end{array}$ \\
\hline 4 & Standard cover of a street tree & $4 m^{2}$ & \\
\hline 5 & Distance between trees & $6 m$ & $\begin{array}{l}\text { Thus, each tree would } \\
\text { 'cover' } 12 \mathrm{~m}^{2} \text { of sidewalk }\end{array}$ \\
\hline 6 & Total available sidewalk area & $17,840 \mathrm{~m}^{2}$ & {$[2] \times[3]$} \\
\hline 7 & $\begin{array}{l}\text { Possible No of street trees in } \\
\text { domain }\end{array}$ & 1,486 & {$[6] \div([5] \times 2)$} \\
\hline 8 & Total possible street tree cover & $5,947 m^{2}$ & {$[7] \times[4]$} \\
\hline 9 & $\begin{array}{l}\text { Possible street cover as a fraction of } \\
\text { total domain area }\end{array}$ & $3.72 \%$ & {$[8] \times 100 \div[2]$} \\
\hline 10 & Current built cover & $52.42 \%$ & Measured from GIS maps \\
\hline 11 & Usable building cover & $40 \%$ & $\begin{array}{l}\text { Based on a visual inspection } \\
\text { of domain area for buildings } \\
\text { with flat roof }\end{array}$ \\
\hline 12 & Total usable building area & $33,549 m^{2}$ & {$[10] \times[11] \times[2]$} \\
\hline 13 & $\begin{array}{l}\text { Total usable building area as a } \\
\text { fraction of domain }\end{array}$ & $21 \%$ & {$[12] \div[2]$} \\
\hline 14 & Assumed average height of building & $12 m$ & Based on visual inspection \\
\hline 15 & Total No of block in domain & 13 & Based on visual inspection \\
\hline 16 & Average block size & $35 \mathrm{~m} \times 30 \mathrm{~m}$ & \\
\hline 17 & Total available Façade area & $10,140 m^{2}$ & {$[16] \times[14] \times[15]$} \\
\hline 18 & $\begin{array}{l}\text { Total usable façade area as a } \\
\text { fraction of domain area }\end{array}$ & $6.34 \%$ & {$[17] \times 100 \div[2]$} \\
\hline
\end{tabular}


Table 8: Alternative approaches to increasing green cover by $20 \%$ in Gla. CC-W

\begin{tabular}{|c|c|c|c|c|c|}
\hline Scenario & $\begin{array}{l}\text { Permeable } \\
\text { vegetated } \\
\text { area }\left(\mathrm{m}^{2}\right)\end{array}$ & $\begin{array}{l}\text { Street } \\
\text { trees } \\
\text { (Nos.) }\end{array}$ & $\begin{array}{l}\text { Intensive } \\
\text { Roof } \\
\text { Garden } \\
\left(\mathrm{m}^{2}\right)\end{array}$ & $\begin{array}{l}\text { Extensive } \\
\text { Roof } \\
\text { Garden } \\
\left(\mathrm{m}^{2}\right)\end{array}$ & $\begin{array}{l}\text { Green } \\
\text { façade }\end{array}$ \\
\hline 1. A large park only & 1,056 & & & & \\
\hline 2. Street trees only & & 528 & & & \\
\hline $\begin{array}{l}\text { 3. } 50 \% \text { of additional greenery in } \\
\text { street tree, balance intensive } \\
\text { roof garden }\end{array}$ & & 264 & 755 & & \\
\hline $\begin{array}{l}\text { 4. } 50 \% \text { of additional greenery in } \\
\text { street tree, balance } \\
\text { extensive roof garden }\end{array}$ & & 264 & & 1,056 & \\
\hline $\begin{array}{l}\text { 5. Mix of intensive (50\%) and } \\
\text { extensive }(50 \%) \text { roof garden }\end{array}$ & & & 755 & 1,056 & \\
\hline $\begin{array}{l}\text { 60\% of all 'sun facing' (i.e. } \\
\text { South \& West) façade } \\
\text { covered façade green }\end{array}$ & & & & & 1,268 \\
\hline
\end{tabular}




\section{List of Figures}

Figure 1: Quantification of land cover types

Figure 2: Detailed view of LCZ classes with built cover categories

Figure 3: Selected locations for model simulations

Figure 4: Three dimensional view of selected sites showing the built- and green-cover

Figure 5: Glasgow city simulation sites (Note: Both Gla CC-W and Gla CC-E are included in this image)

Figure 6: Glasgow Clyde Gateway simulation site

Figure 7: Paisley simulation site

Figure 8: Wishaw simulation site

Figure 9: Hamilton simulation site

Figure 10a: Temperature profile comparison of measured (GCU Weather Station) and simulated (ENVI-met) temperatures in Glasgow on 30 April 2011

Figure 10b: Scatter plot of ENVI-met predicted and measured temperatures

Figure 11: Air temperature effect of green infrastructure - daytime

Figure 12: Air temperature effect of green infrastructure - night time

Figure 13: Average daily summertime effects

Figure 14: Average daily summertime temperature effect of green cover

Figure 15: Surface temperature effects at daytime

Figure 16: Surface temperature effects at nighttime 


\section{Built cover and $L C Z$ classes}
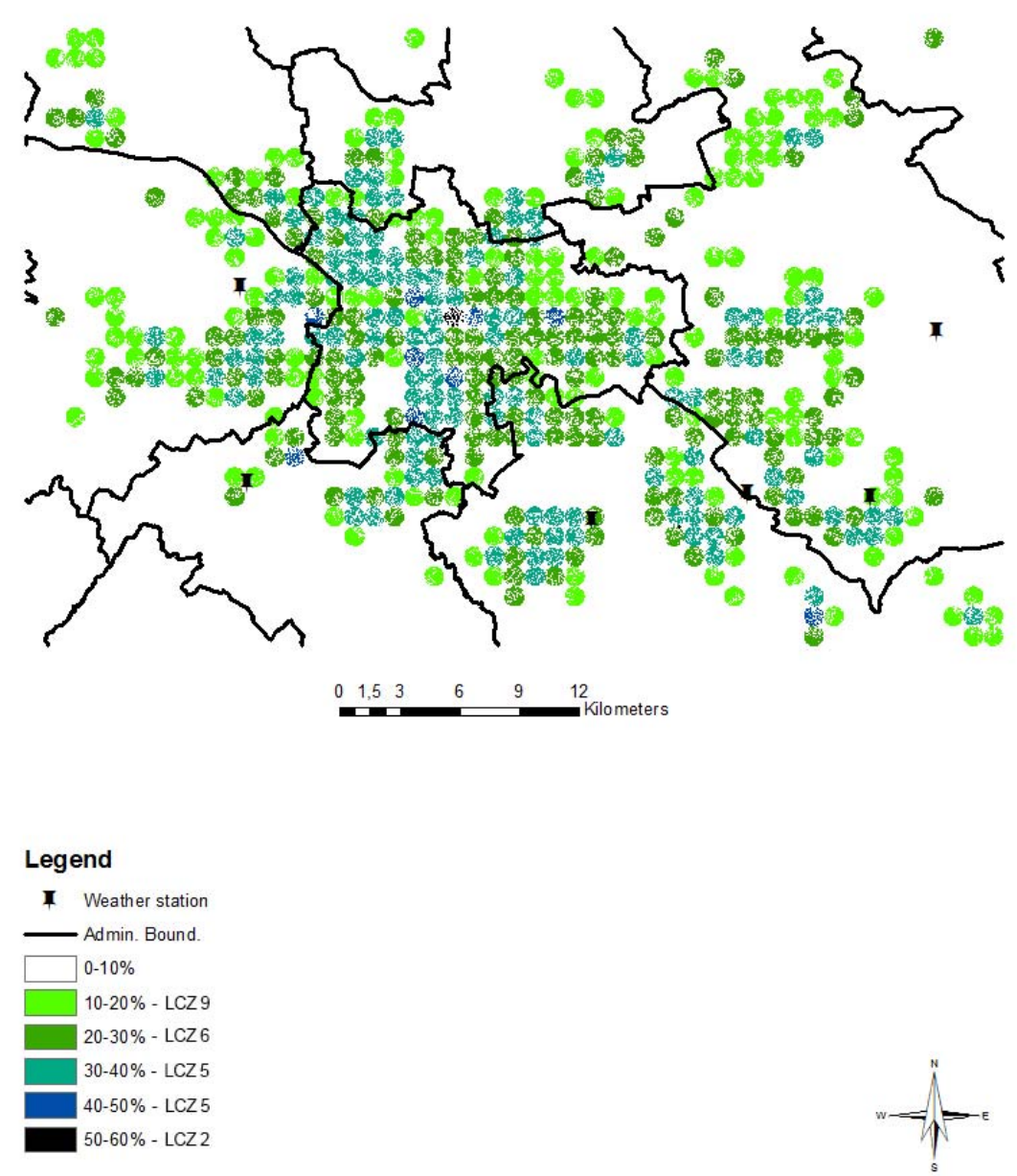

Figure 1: Detailed view of LCZ classes with built cover categories 


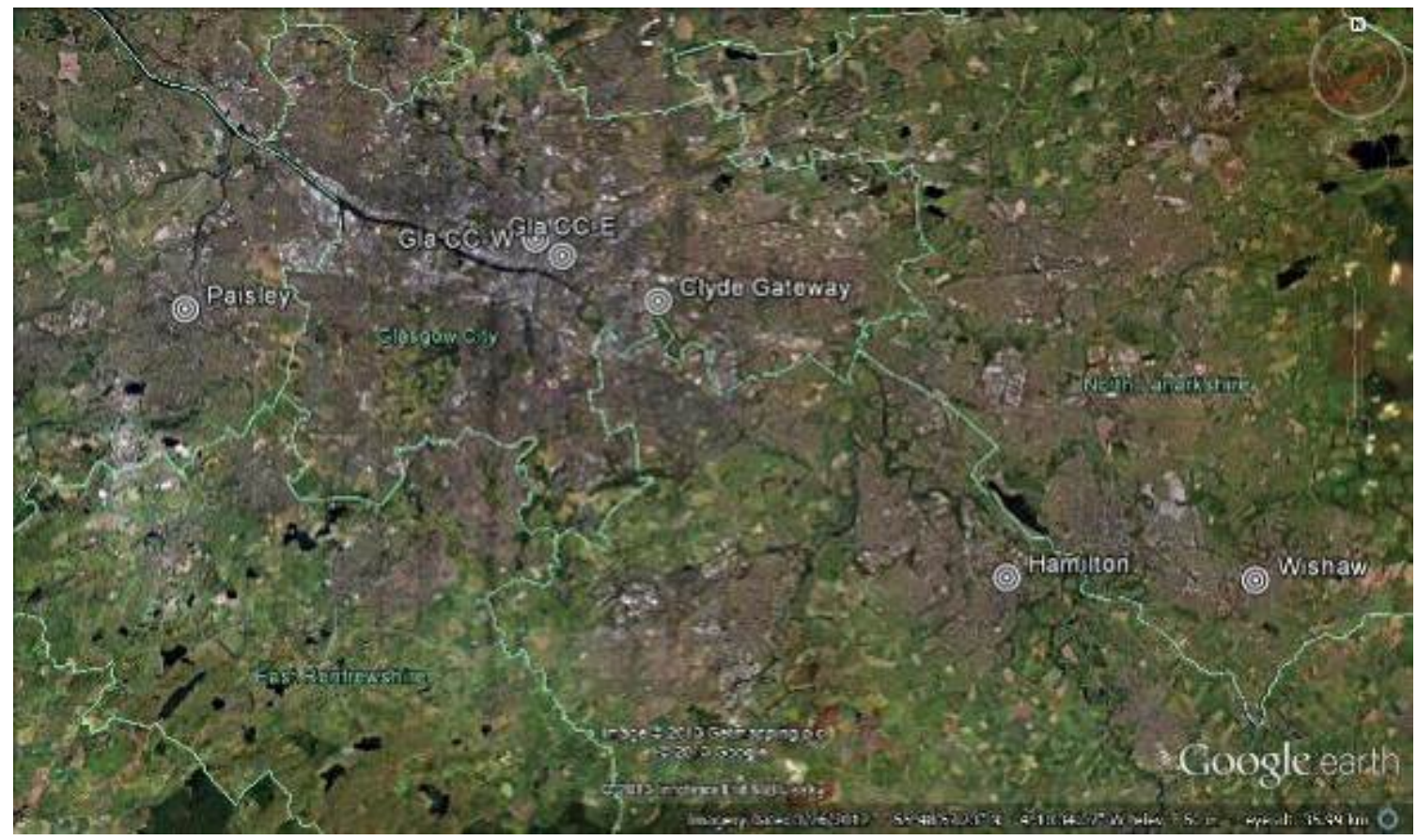

Figure 2: Selected locations for model simulations 


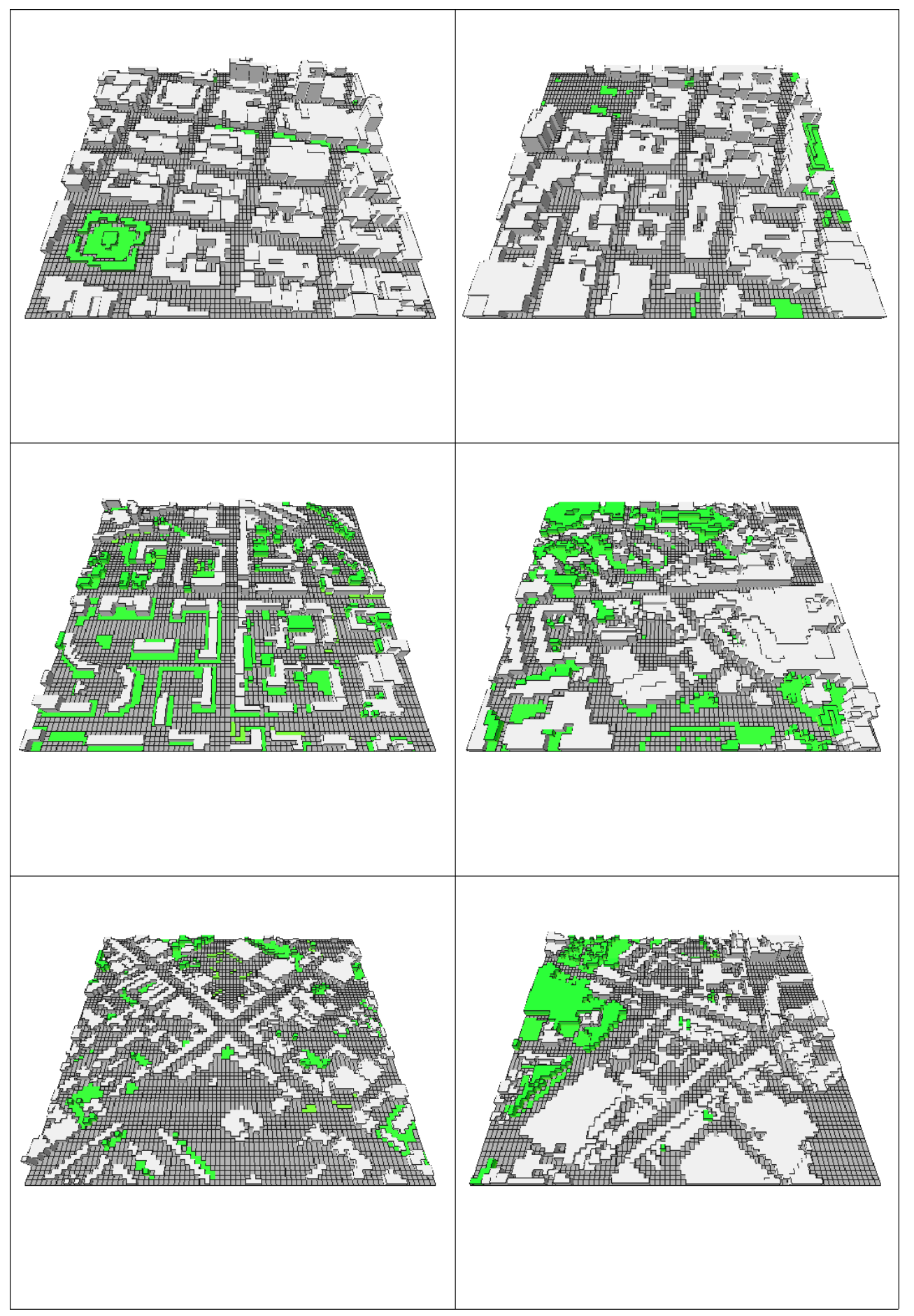

Figure 3: Three dimensional view of selected sites showing the built- and green-cover 
Top left: Glasgow City Centre west; Top right: Glasgow City Centre east

Middle left: Glasgow Clyde Gateway; Middle right: Paisley

Bottom left: Wishaw; Bottom right: Hamilton 


\section{Glasgow}

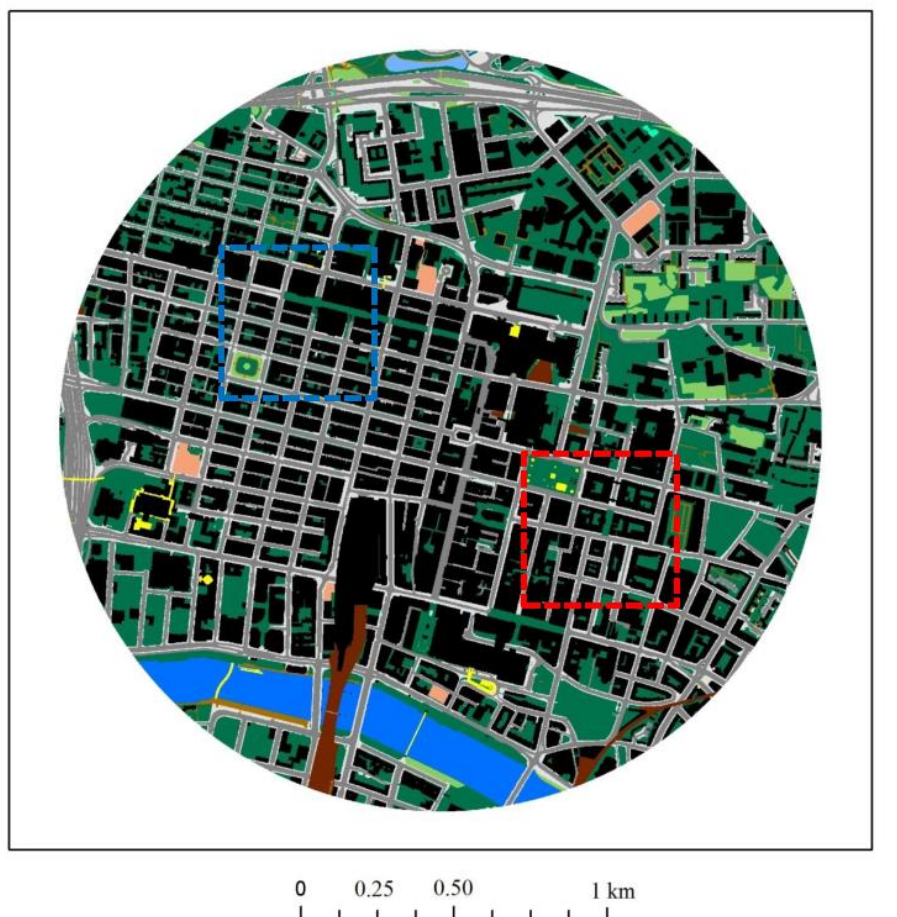

\section{Legend}

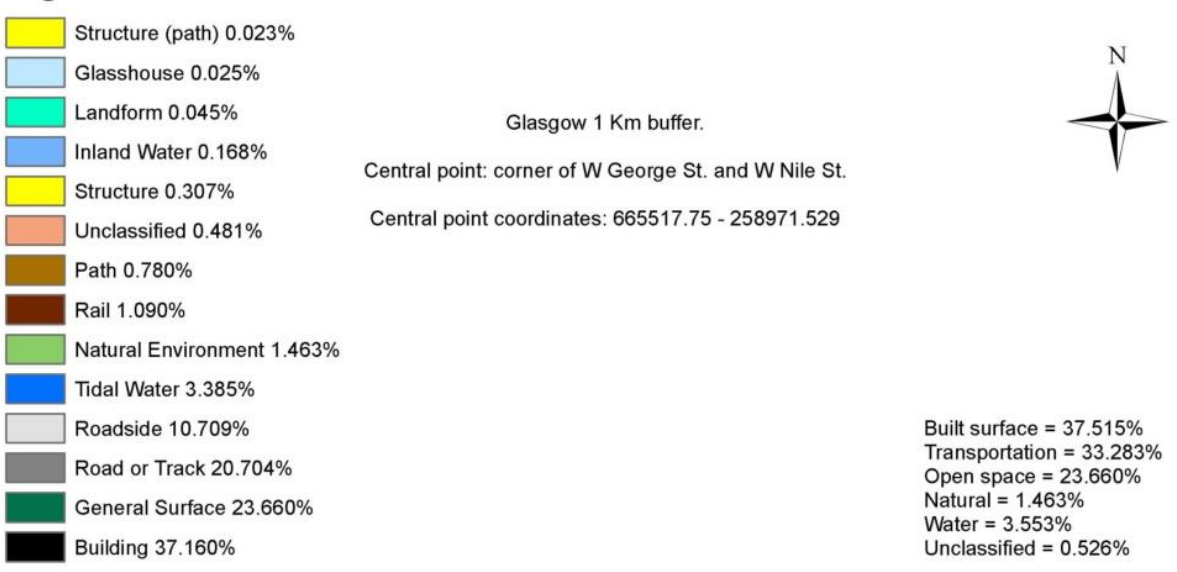

Figure 4: Glasgow city simulation sites (Gla CC-W: blue square; Gla CC-E: red square)

Note: Both Gla CC-W (blue square) and Gla CC-E (red square) are included in this image 


\section{Glasgow - Eastside}

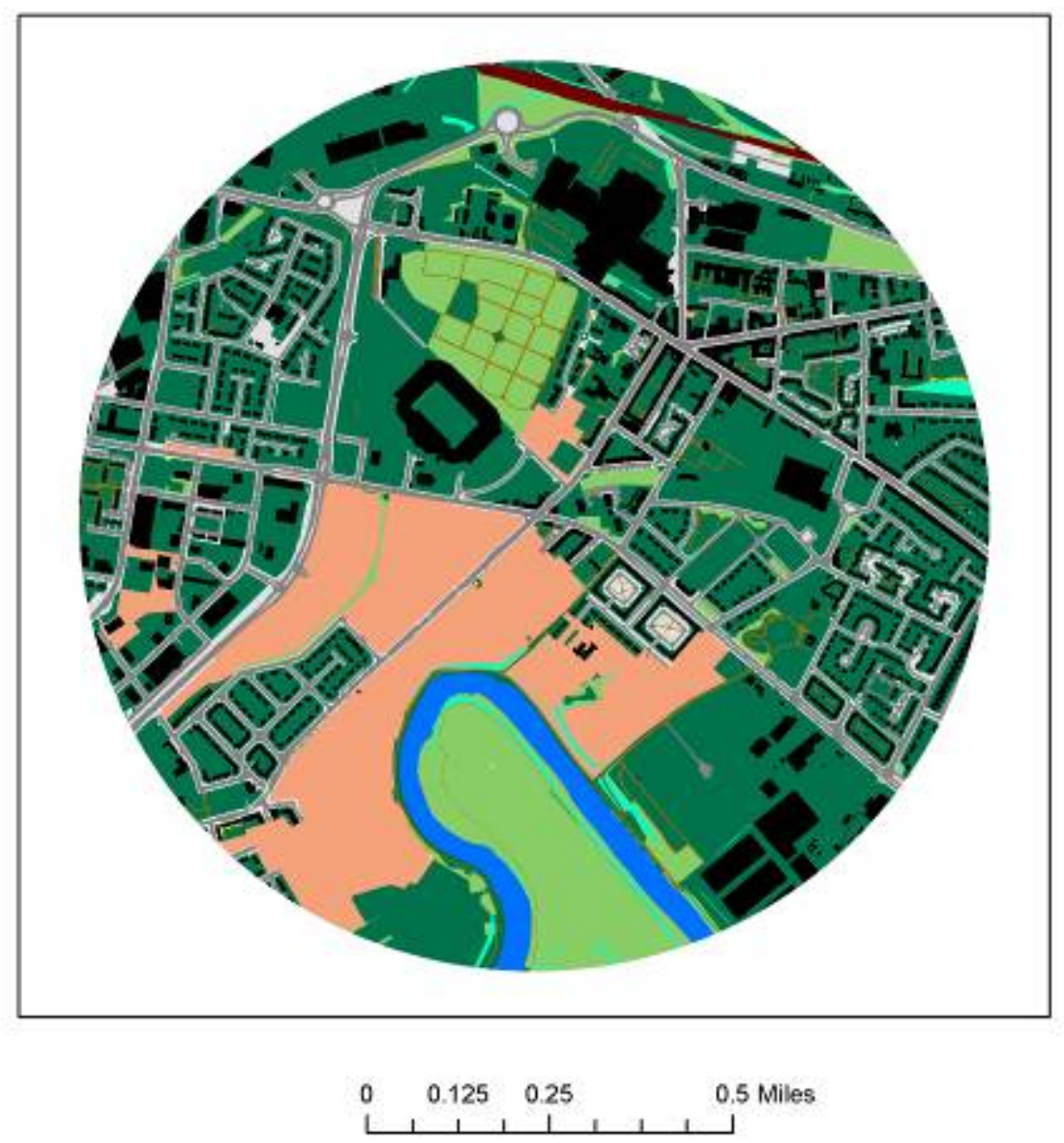

\section{Legend}

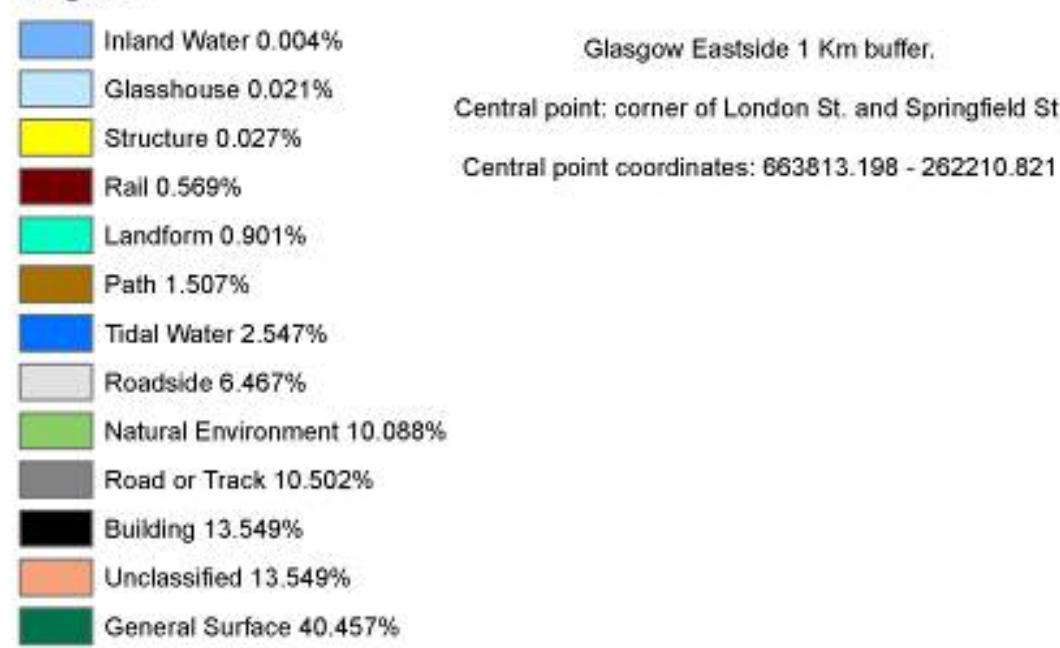

Built surface $=13.597 \%$

Transportation $=19,045 \%$

Open space $=40.457 \%$

Natural $=10.088 \%$

Water $=2.551 \%$

Unclassified $=14.45 \%$

Figure 5: Glasgow Clyde Gateway simulation site 


\section{Paisley}

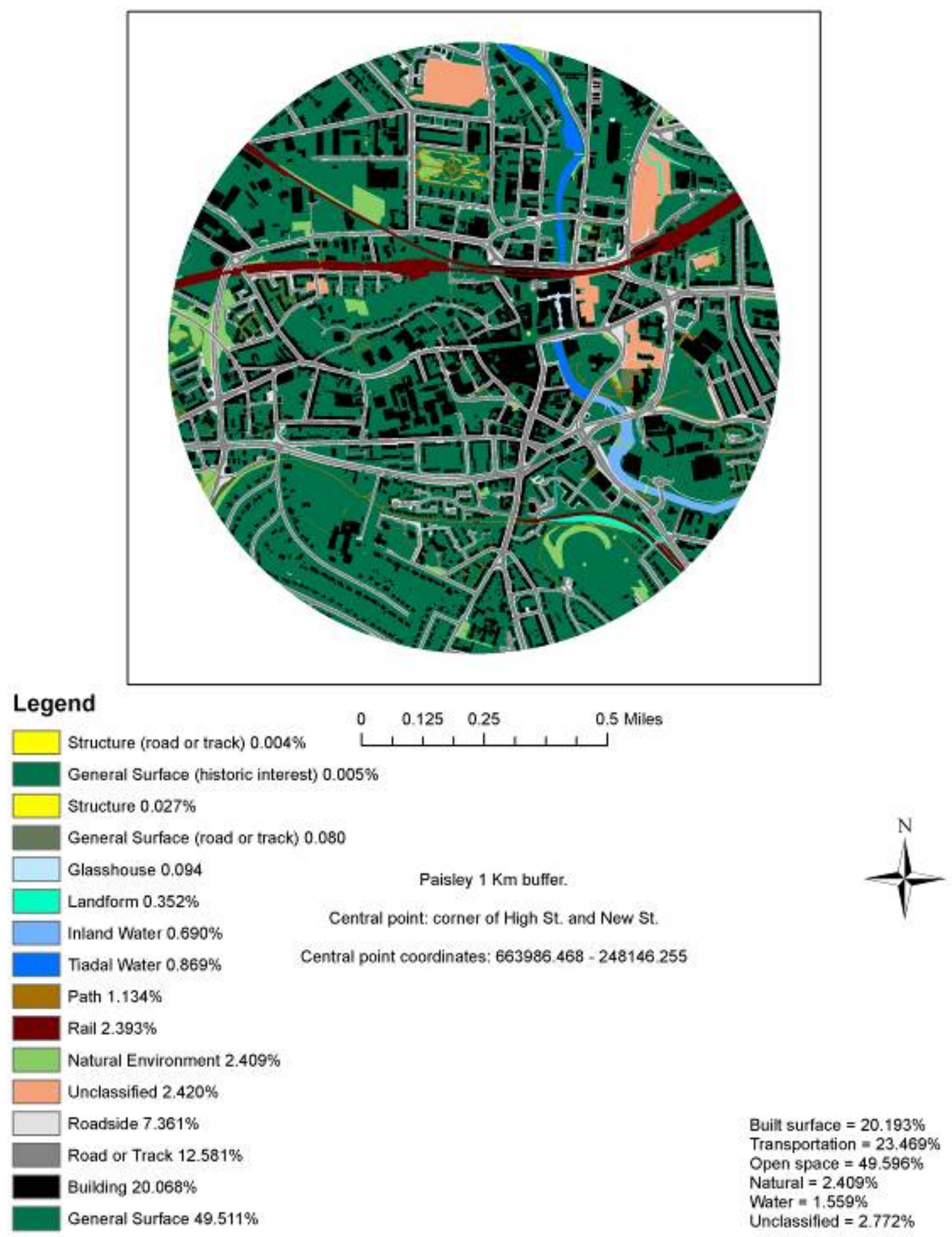

Figure 6: Paisley simulation site 


\section{Wishaw}

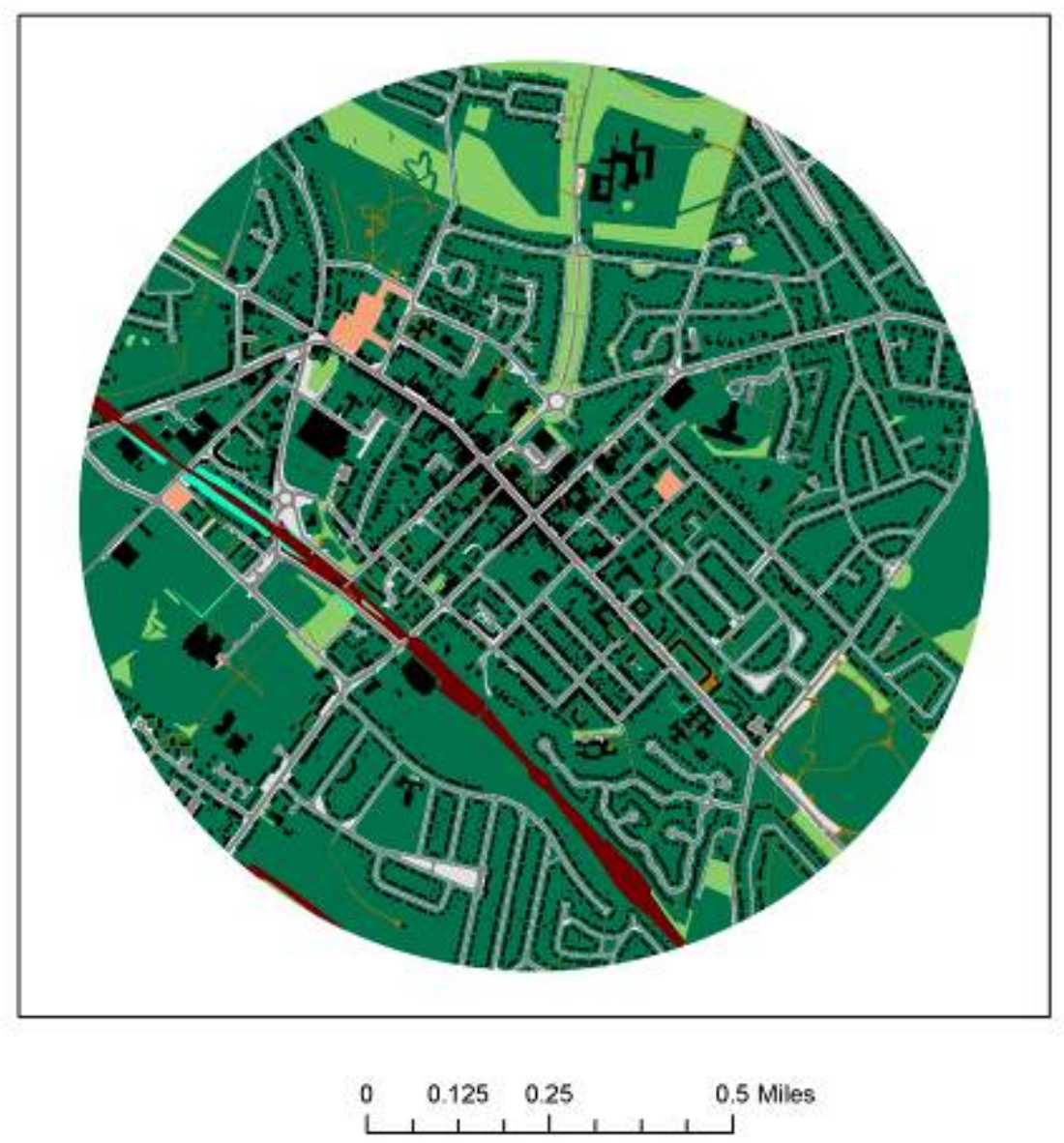

\section{Legend}

\begin{tabular}{|l}
\hline Structure $0.005 \%$ \\
\hline Glasshouse 0.011 \\
Inland Water 0.048 \\
Landform 0.337 \\
\hline Unclassified $0.500 \%$ \\
Path $1.174 \%$ \\
Rail $1.716 \%$ \\
Natural Environment $5.957 \%$ \\
\hline Roadside $6.027 \%$ \\
Road or Track $9.489 \%$ \\
Building $13.043 \%$ \\
\hline General Surface 61.692
\end{tabular}

Wishaw $1 \mathrm{Km}$ buffer.

Central point corner of Caledonian Rd, and Main St.

Central point coordinates: $655216.761-272538.736$

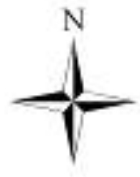

Built surface $=13.059 \%$

Transportation $=18.406 \%$

Open space $=61.692 \%$

Natural $=5.957 \%$

Water $=0.048 \%$

Unclassified $=0.837 \%$

Figure 7: Wishaw simulation site 


\section{Hamilton}

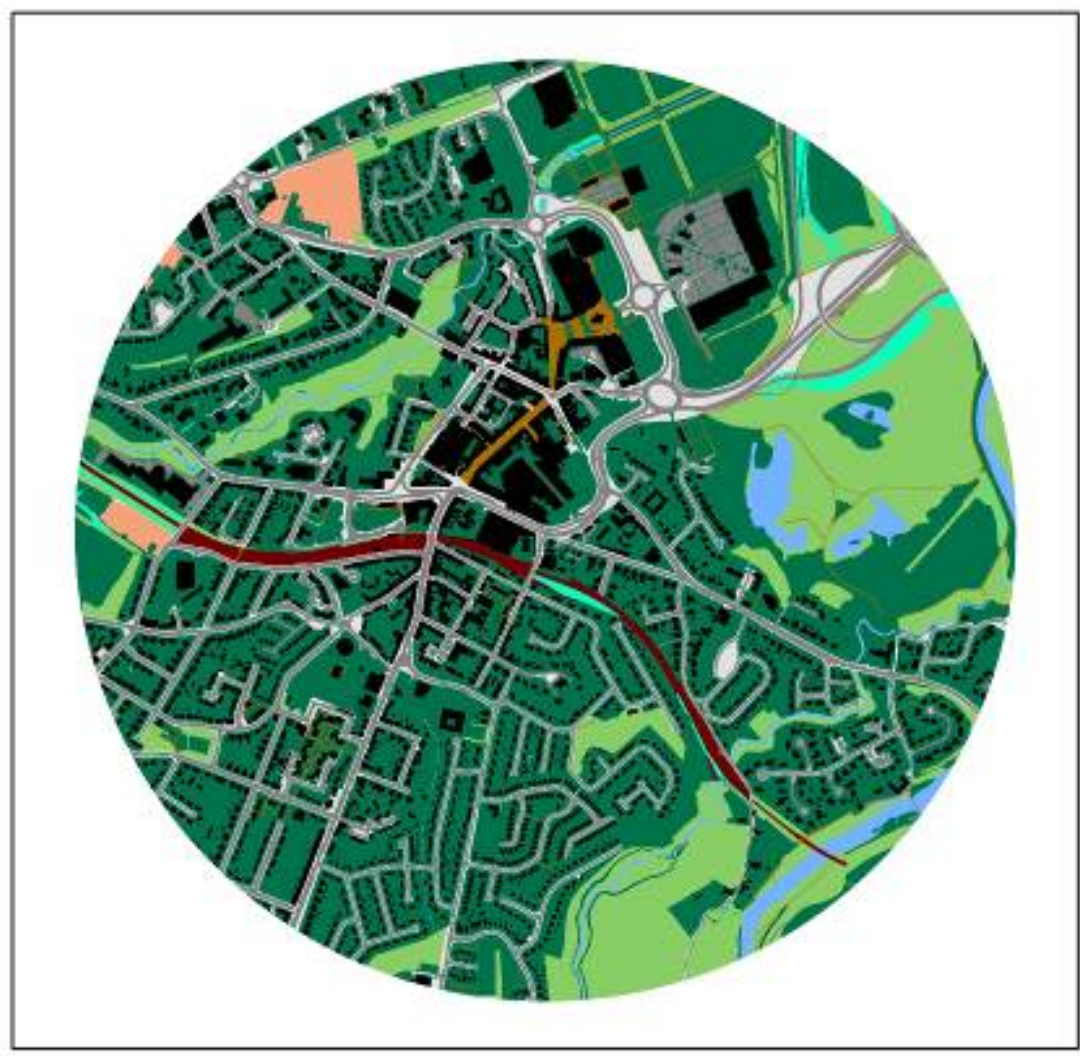

\section{Legend}

Glasshouse $0.007 \%$

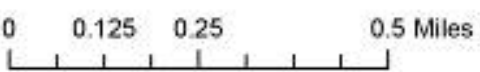

Structure $0.007 \%$

Landform (road or track) $0.021 \%$

General Surface (road or track) $0.036 \%$

Natural Environment (road or track) $0.180 \%$

\section{Landform $0.958 \%$}

Unclassified 1.119

Hamilton $1 \mathrm{Km}$ buffer.

Rail $1.160 \%$

Central point: corner of Brandon St. and Quarry St.

Path $1.381 \%$

Central point coordinates: 655018.197 - 279691.272

Inland Water $2.188 \%$

Roadside $6.451 \%$

Road or Track $10.855 \%$

Building $13.982 \%$

Natural Environment $15.466 \%$

General Surface $46.171 \%$

Built surface $=13.996 \%$

Transportation $=19.847 \%$

Open space $=46.207 \%$

Natural $=15.646 \%$

Water $=2.188 \%$

Unclassified $=2.098 \%$

Figure 8: Hamilton simulation site 


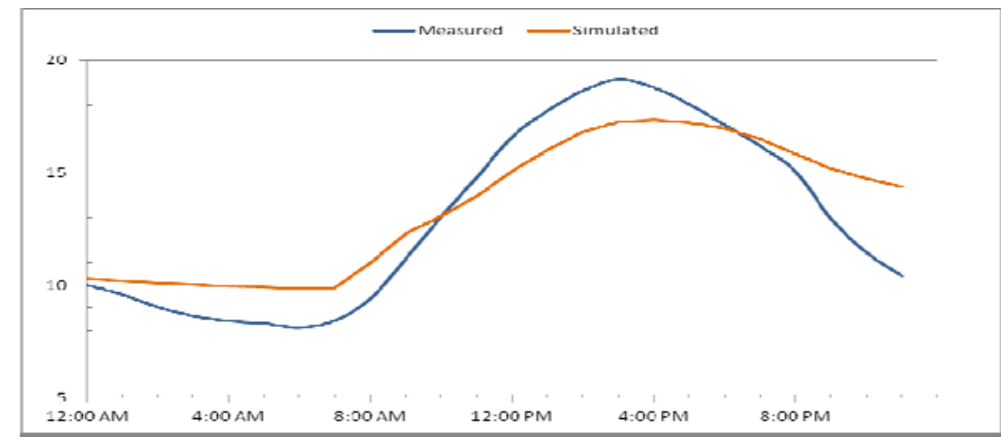

Figure 9: Comparison of measured (GCU Weather Station) and simulated (ENVI-met) temperatures in Glasgow on 30 April 2011 
Effect over the 2050 base case

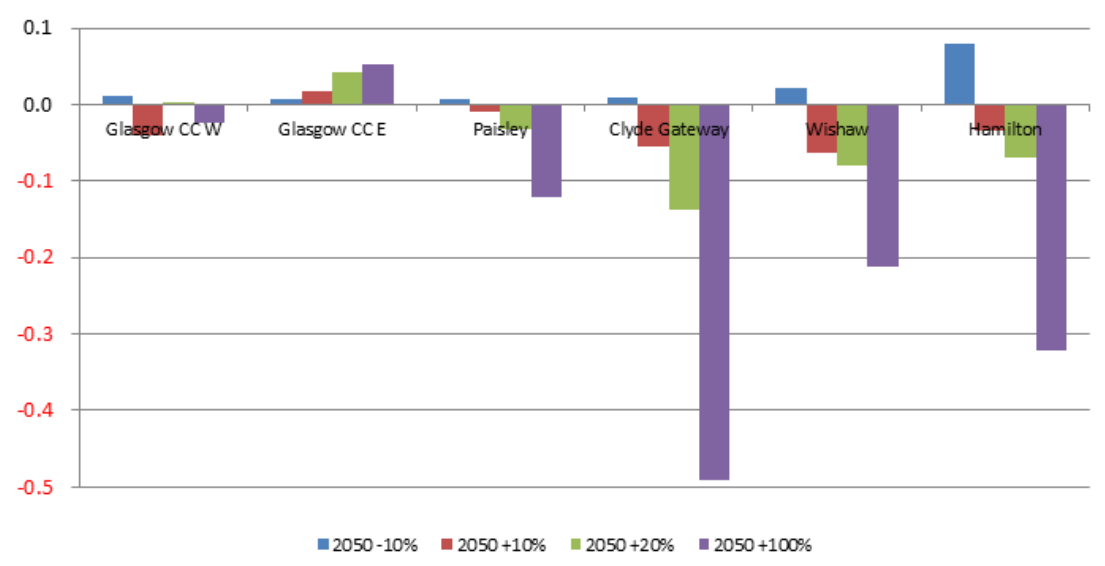

Figure 10: Air temperature effect of green infrastructure - daytime

Notes:

The slight increase in temperature at Glasgow CC-E is an artefact of the location of the changes in green cover relative to the point for which the data is plotted in the figure above. An area averaged change in temperature, as detailed in Table 2 is more representative of the cooling effect in the entire simulated domain area.

\section{Effect over the 2050 base case}

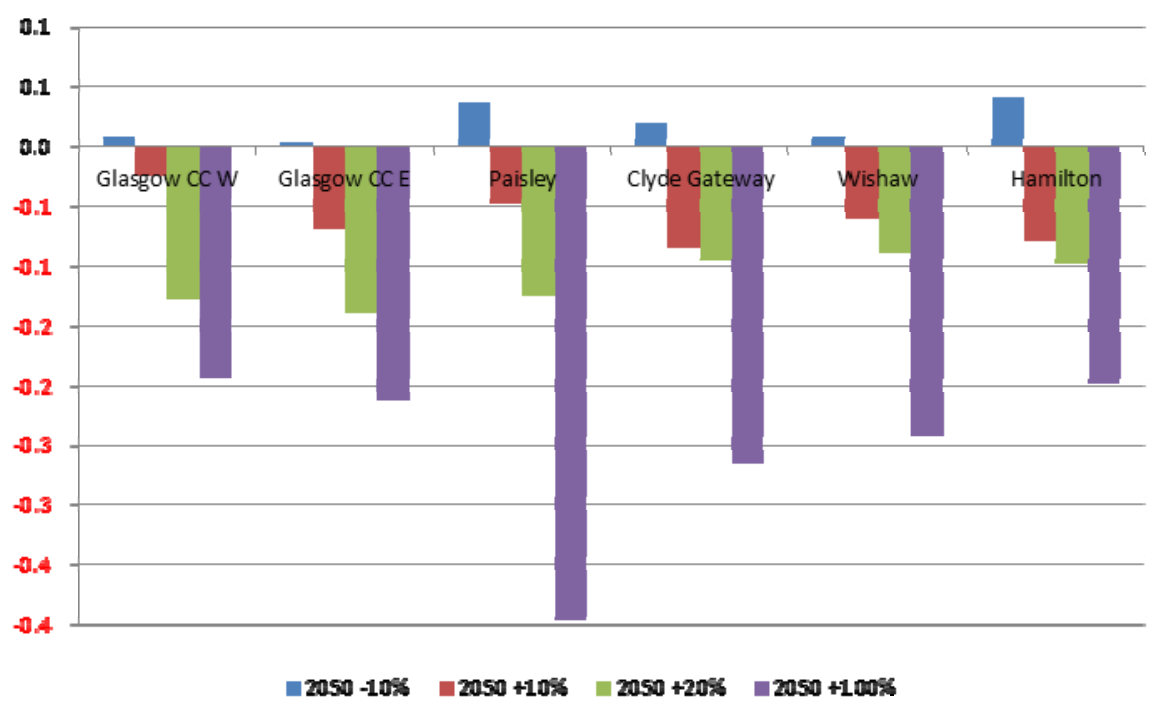

Figure 11: Air temperature effect of green infrastructure - night time 
Effect over 2050 base case

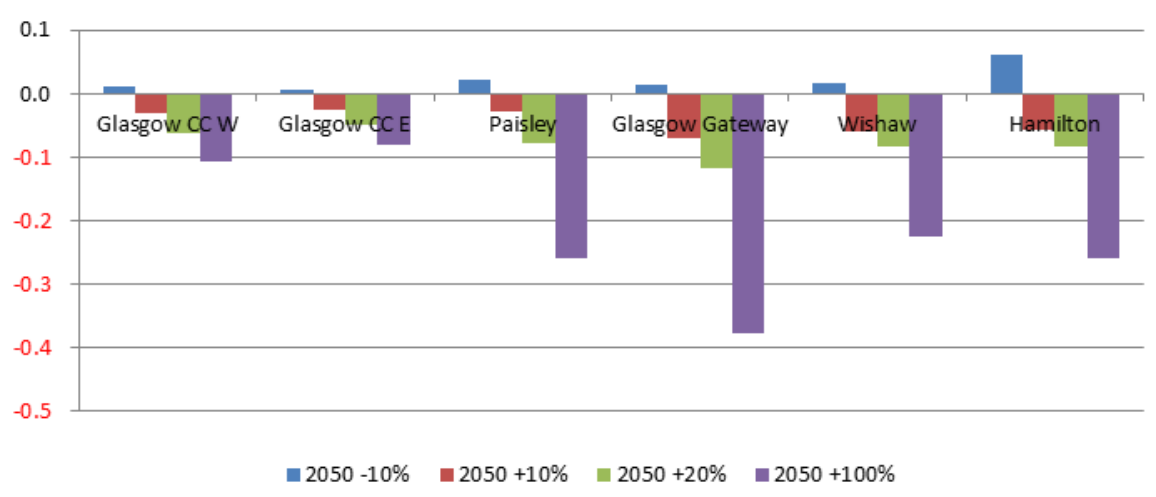

Figure 12: Average daily summertime effects

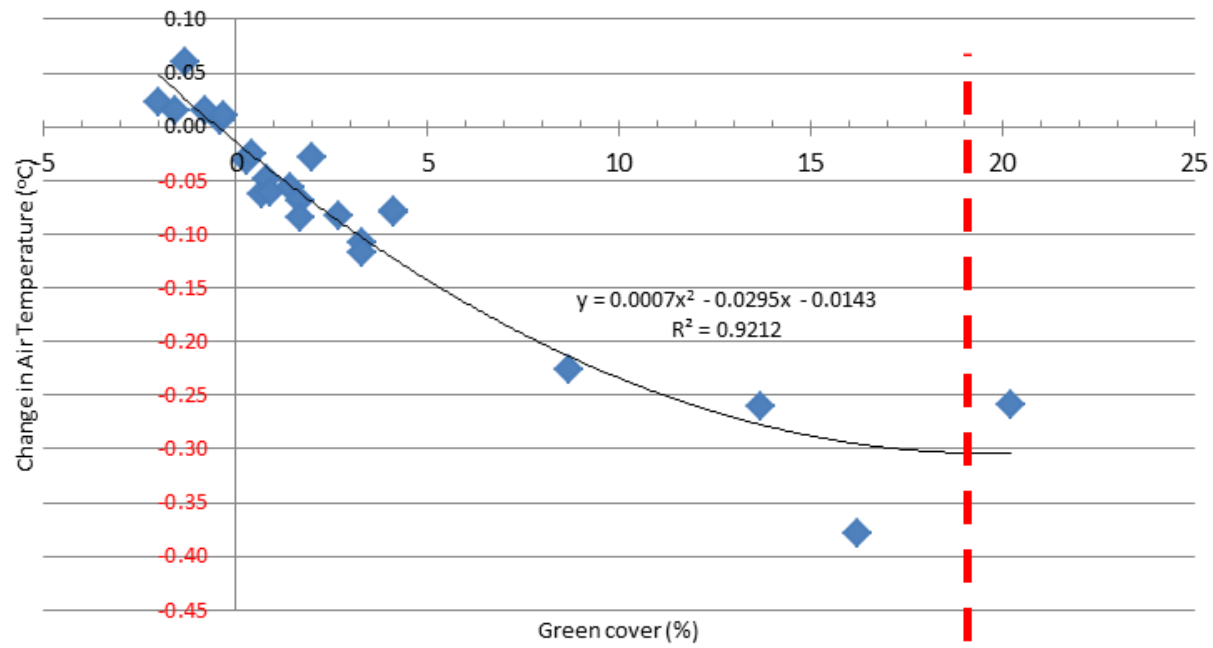

Figure 13: Average daily summertime temperature effect of green cover 


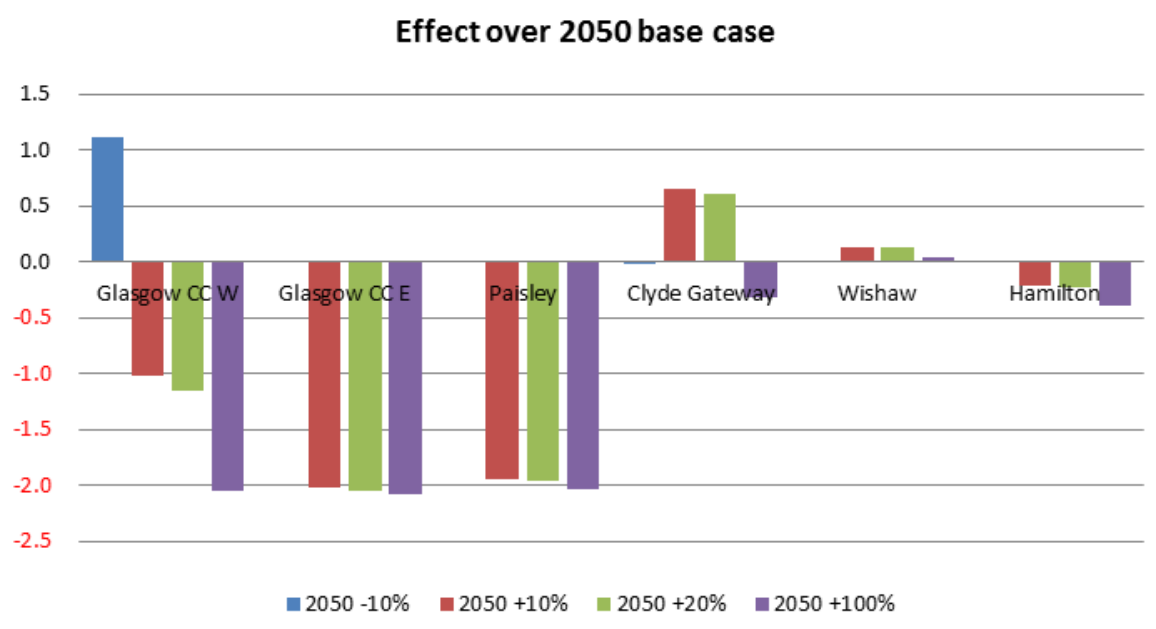

Fig 14: Surface temperature effects at daytime

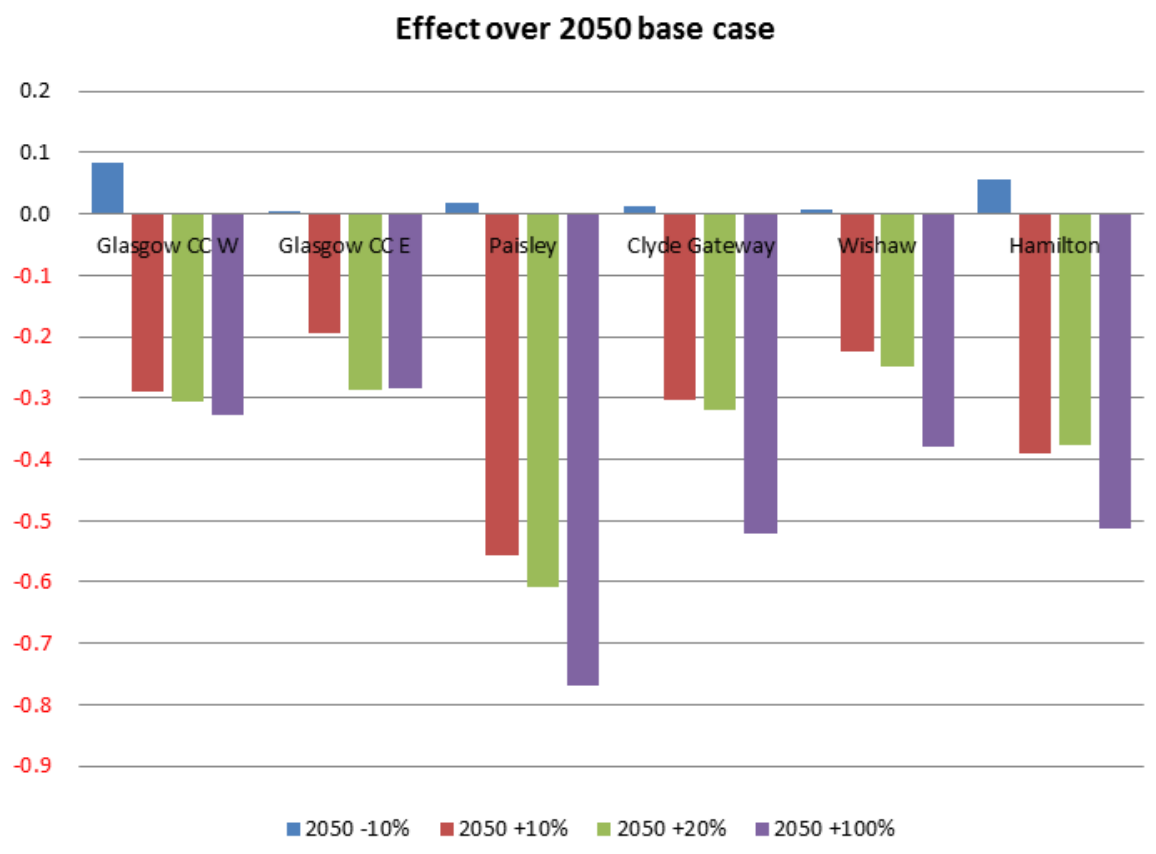

Fig 15: Surface temperature effects at nighttime 